University of Louisville

ThinkIR: The University of Louisville's Institutional Repository

Electronic Theses and Dissertations

1931

\title{
The influence of the brain upon the liver as a blood concentrating organ in fever.
}

Benjamin F. Aydelotte 1899-1956

University of Louisville

Follow this and additional works at: https://ir.library.louisville.edu/etd

Part of the Circulatory and Respiratory Physiology Commons, Hematology Commons, and the Medical Pathology Commons

\section{Recommended Citation}

Aydelotte, Benjamin F. 1899-1956, "The influence of the brain upon the liver as a blood concentrating organ in fever." (1931). Electronic Theses and Dissertations. Paper 1673.

https://doi.org/10.18297/etd/1673

This Master's Thesis is brought to you for free and open access by ThinkIR: The University of Louisville's Institutional Repository. It has been accepted for inclusion in Electronic Theses and Dissertations by an authorized administrator of ThinkIR: The University of Louisville's Institutional Repository. This title appears here courtesy of the author, who has retained all other copyrights. For more information, please contact thinkir@louisville.edu. 


\title{
UNIVERSITY OF LOUISVILLE
}

THE INFLUENCE OF THE BRAIN UPON

THE LIVER AS A BLOOD CONCENTRATING

ORGAN IN FEVER.

\author{
A Dissertation \\ Submitted to the Faculty \\ Of the Graduate School of the University of Louisville \\ In Partial Fulfillment of the \\ Requirements for the Degree \\ of Master of Science
}

Department of Physiology

By

BENJAMIN F. AYDELOTTE

1931 
CONTENTS

INTRODUCTION .......................... I

Factors Involved in Fluid Shifting During Fever.

I. INVESTIGATIONS FOR A NERVOUS CONTROL OF BLOOD CONCENTRATION.

Procedure $\ldots \ldots \ldots \ldots \ldots \ldots \ldots \ldots \ldots \ldots \ldots \ldots \ldots \ldots \ldots \ldots$

Results $\ldots \ldots \ldots \ldots \ldots \ldots \ldots \ldots \ldots \ldots \ldots \ldots \ldots \ldots \ldots \ldots$

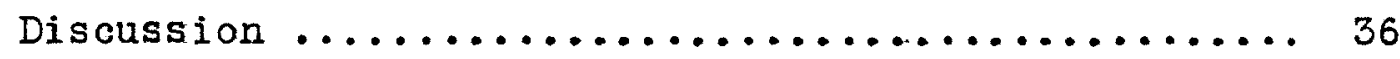

II. INVESTIGATIONS OF THE LIVER AS A WECHANISM FOR

WHE CONTROL OF BLOOD CONCENTRATION.

Frocedure $\ldots \ldots \ldots \ldots \ldots \ldots \ldots \ldots \ldots \ldots \ldots \ldots \ldots \ldots \ldots$

Results $\ldots \ldots \ldots \ldots \ldots \ldots \ldots \ldots \ldots \ldots \ldots \ldots \ldots \ldots \ldots \ldots \ldots$

Discussion $\ldots \ldots \ldots \ldots \ldots \ldots \ldots \ldots \ldots \ldots \ldots \ldots \ldots \ldots$

Microscopic Investigation ................... 49

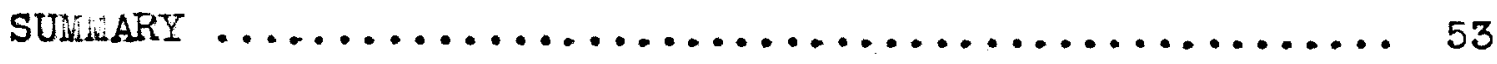

CONCLUSIONS $\ldots \ldots \ldots \ldots \ldots \ldots \ldots \ldots \ldots \ldots \ldots \ldots \ldots \ldots \ldots \ldots \ldots \ldots$

BIBLIOGRAPHY $\ldots \ldots \ldots \ldots \ldots \ldots \ldots \ldots \ldots \ldots \ldots \ldots \ldots \ldots \ldots \ldots \ldots \ldots \ldots$ 
THE INFLUENCE OF THE BRAIN UPON THE LIVER AS A BLOOD CONCENTRATING ORGAN IN FEVER. 
INTRODUC TION 


\section{INTRODUCTION}

Blood concentration in fever and dilution on remission is indicative of important fluid shifting in the body. The liver was shown last year by H.T. Marshall (18) to account chiefly for the fluid lost from the blood in toxic fever induced in rabbits by optimal doses of cocaine, after the work of Barbour and Moise (4). These considerations of the fluid shifting in fever are restricted to possible depots where the water is retained in the body; and in animals killed during cocaine fever, the liver was the only tissue which would account by reduced solids for the fluid lost from the blood. The spleen as a factor in blood concentration seems by the work of Lamson (21) and others to have been relegated to a minor position. (See also Krumbhaar (19) This has been confirmed by the author who found that cold produced a substantial increase in blood specific gravity in dogs after splenectomy; the concentration occuring principally in the plasma.

The object of this present work was to throw light on the mechanism through which the liver is induced to take up fluid from the blood; and here two logical lines of investigation are presented in the chemistry and in the nervous control of liver function. 
On the chemical side the manner in which salts influence the movement of water, and subsequently influence the ion balance, especially the H-ion, was shown (6) by injecting various salts into the portal vein. Salts thus injected influence tremendously the action of the liver on the circulating blood in rabits. In the procedure mentioned above, the liver was shown to have a selective retention for certain ions, particularly $\mathrm{Na}$ and $\mathrm{Cl}$. When relatively large amounts of $\mathrm{NaCl}$ were injected into the portal vein of either rabbits or dogs there was a relative decrease of the injected salt in the systemic circulation well as a loos of fluid from the blood as shown by $\mathrm{Hb}$ determinations. Solutions of $\mathrm{Ca}$ and $\mathrm{K}$ salts, on the other hand, produced an opposite effect.

Storage products such as glycogen and proteins would also effect the osmotic pressure relationship of blood and liver as was shown a long time ago by the histological studies of the liver by means of specific dyes (1). The storage of food materials such as glycogen and protein has made the liver an organ of interest in metabolism as related to the physiology of the organisms reaction to cold. It was through these latter investigations, Plant (14) et al that our present procedure was suggested. Plant denervated the liver of dogs and rabbits and made subsequent studies of metabolism. In these investigations the liver de- 
nervation was found to impair body temperature regulation.

Work on the movement of water by chemical changes such as the transfer of ions and metabolic products has already been started but the present discussion will be limited to the nervous factors in control of fluid movement in fever. Turning to the nervous control of water movement in the body and the dependence of blood concentration on the central nervous system was investigated by Barbour and Tolstoi (5), who showed that the blood concentrating function was impaired in decerebrate dogs, these dogs were deprived of the basal ganglia. This was also shown to be true for dogs having cervical cord transection. This dependence of the water balance on the central nervous system was also demonstrated by Rogers (17) in pigeons which were deprived of their basal ganglia. In these birds the ability to retain water was lost. Another interesting nervous mechanism related directly to the liver was demonstrated by Mautner and Fick (13) who showed that there was a constrictor mechanism in the hepatic vein of dogs, mechanism which causes blood to be retained in the liver. However this condition does not hold for rabbits in as much as they are herbivorous and the masclature of the hepatic vein is missing or too slight to make it an effective mechanism.

The brain puncture method used by Barbour (20) et al, offered a convenient approach to the consideration of a central nervous control of the liver, since a good and comparative- 
ly rapid onset of fever follows a puncture of the brain, particularly the basal ganglia to which region the heat regulating nervous mechanism is relegated.'

Neurogenic fevers were first produced in rabbits in order to determine whether or not blood concentration was an accompanying phenomenon as it was in toxic fevers induced in rabbits as Marshall (18) has shown. If this blood concentration did result, then fluid lost from the blood could be accounted for in the liver as was the case in toxic fevers; and if the above speculation could be confirmed by experiment under like conditions, the behavior of the denervated liver would then afford a further significant method of attack. 
Investigations of Blood Concentration in Simple Heat Puncture and "Cold Fever" Supplemented by the Contracted Effects of Heating Basal Ganglia. 
Investigation of Blood Concentration in Simple Heat Puncture and "Cold Fever" Supplemented by the Contracted Effects of Heating Basal Ganglia.

\section{Procedure.}

Normal rabbits, free from snuffles or any other febrile condition were used, care being exercised in the use of females to conclusively show that they were not pregnant. ihe animals had water before them up to the time of operation but food was withheld from them over night.

The operative technique consisted in shaving the head from the occiput to half the distance of the face as an aid in the stringent aseptic methods of operation. Under ether anesthesia, an incision of approximately four centimeters length was made in the mid line beginning just anterior to the ears, the connective tissue and aponeurosis was freed from the bone in the region of the coronal suture and at the intersection of the cornal suture and mid line the skull was entered by $5 \mathrm{~mm}$ trephine; a triangular shaped window was made in the dura with small scissors in order to facilitate the subsegment puncture and to avold rupturing of the superior sinus. Into the aperatare thus prepared, a small threaded plug was screwed and fixed by building up a dressing of collodin and cotton wich also made en air tight dressing. After puncture was made with the $u$ shaped 
hollow tube, more collodin and cotton was applied in order to make the whole firm against chance bumping of the head and also to prevent infection by contamination.

The animals operated on as above recovered their normal posture, coordinated movements and temperature in a normal range within two or three hours. Since most of the operations were done early in the morning recovery was attained by $2: 00$ P.M.

Blood for specific gravity determinations was obtained from the marginal ear vein and determinations made by the falling drop method (2). Rectal temperature was read from a standard rectal $\mathrm{HE}$ thermometer inserted to approximately $6 \mathrm{~cm}$ depth into the rectum, care being taken that the thermometer was always shaken down to a common reading before insertion. The animal was always placed on a well padded table and allowed a normal resting position without restraint by ties or handing. Quiet was effected as nearly as possible in as much as excitement effects a marked blood concentration.

The heat and cold was supplied by hot and cold water from 5 gallon jars well insulated by sawdust packing from which stop cork siphons were led to the hollow tube inserted in the rabbit's head. No water, tubing or any of the apparatus was allowed to touch the rabbit except through the hollow tube. The room temperature was maintained at about $25^{\circ} \mathrm{C}$; most of ten the rabbit 
recovered in the room in which the experimentation was made. The experiments done were almost identical as shawn by the following represcutative group.

\section{Observations.}

Rabbit No. 3, October 9,1930 - a white male rabbit, 2600 gms. weight, was operated on at 9:15 A.M. as described under ether. The heat puncture was made at 9:30 A.M. At 1:20 P.M. the animal was well recovered; respiration good, posture was normal, coordinated muscular movements and normal reflexes were present. In the period from $1: 20$ to $2: 18$ P.M. the rectal temperature remained undisturbed; the blood specific gravity was 1.043 . At $2: 20$ P.M. water at $48^{\circ} \mathrm{C}$ was run through the tube heating the basal ganglia and in six minutes the blood specific gravity was reduced to 1.0486 and at $3: 01$ it was further reduced to 1.0410 with a slight temperature increase (see Table I). Breathing was accelerated, body stretched out and ears were very warm. The heat was removed at 3:02 and cold applied at 3:03. The temperature of the water inflow was taken a distance of about $15 \mathrm{~cm}$ from the entrance into the hollow tube. A further drop in specific gravity of the blood occured until 3:10 from which time a steady and rapid increase began and at $3: 20$ the blood specific gravity had again reached 1.042 . At $3: 48$ the blood specific gravity had 
reached 1.0435 ; the animal had become quiet, breathing very slowly with ear vessels constricted and ears cold; there was also some shivering in the jaw muscles. The cold was removed at 4:00 P.M. and there was at that time a slight decrease in rectal temperature. On removal of the cold there was a reaction of the rabbit as if a warm stimulus had been applied. Hot water was again applied at 4:02. At 4:03 the blood specific gravity was 1.0417 with rectal temperature reduced to $106.4^{\circ} \mathrm{F}$. Vaso dilatation and warmth returned to the ears; restlessness appeared with relexation and exposure of body surface. At 4:20 heat was removed and cold applied. The reaction to cold was again effected, blood specific gravity increased to 1.045 at $5: 04$ with rectal temperature increased to $106.8^{\circ} \mathrm{F}$ - Table I, figure I are constructed from this experiment.

There was some difficulty in maintaining an even flow through the canula at first which fact could explain some inconsistencies in the temperature and blood specific gravity relationship which did not appear in later experiments.

October 10,1930. Rabbit No. 4, weighing $2340 \mathrm{gms}$, a white male in good condition having had the same diet and care as the previous rabbits, was operated on at 11:00 A.M. as before for the puncture which was made at 11:15 A.M. Fever from the puncture had risen at 2:00 PM to $105.4^{\circ} \mathrm{F}$. The same vaso motor responses and behavior were present in this animal as in 
TABLE I.

Experiment of 10-9-30. Effects of cooling and heating basal

ganglia on blood concentrations.

\begin{tabular}{|c|c|c|c|c|c|}
\hline$\underset{\text { PM }}{\text { Pime }}$ & $\begin{array}{c}\text { Rectal } \\
\text { I emp. } \\
\text { OF. }\end{array}$ & $\begin{array}{l}\text { blood } \\
\text { Specific } \\
\text { Gravity }\end{array}$ & $\begin{array}{c}\text { Temp. of } \\
\text { applied } \\
\text { water } \\
\text { oc. }\end{array}$ & $\begin{array}{l}\text { Room } \\
\text { temp. }\end{array}$ & REMARKS \\
\hline $1: 35$ & 107.1 & & & 26 & 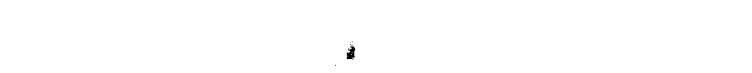 \\
\hline $2: 00$ & & 1.0430 & & & \\
\hline $2: 18$ & & & 47 & & \\
\hline $2: 20$ & 107.1 & 1.0430 & & & Rapid breathing. \\
\hline $2: 26$ & 106.7 & 1.0426 & 48 & & Ears warm. Heat off. \\
\hline $3: 02$ & & & 22 & & Cold on. \\
\hline $3: 03$ & 107.7 & 1.0406 & 16.5 & & Very quiet. Ears are cold. \\
\hline $3: 10$ & 107.4 & 1.0395 & & & \\
\hline $3: 20$ & 107.4 & 1.0422 & & & Breathing slower. \\
\hline $3: 33$ & 107.4 & 1.0430 & 11 & & \\
\hline $3: 48$ & 107.4 & 1.0435 & 10 & & Cold off. \\
\hline $4: 02$ & 107.2 & & 32 & & Heat on. \\
\hline $4: 03$ & 106.6 & 1.0417 & 43 & & \\
\hline $4: 20$ & 106.4 & 1.042 & 30 & 26.5 & Heat off. \\
\hline $4: 22$ & 106.2 & 1.0423 & 20 & & Cola on. Respiration slower.' \\
\hline $4: 27$ & 106.2 & 1.0439 & 18 & & \\
\hline $5: 04$ & & 1.045 & 18 & & Cold off. \\
\hline $5: 05$ & & & 40 & & Rabbit becomes excited. \\
\hline $5: 06$ & & 1.0365 & 47 & & \\
\hline
\end{tabular}


Legend to Figures I to VII Inclusive.

The figures presented here were constructed from the tables preceding each; they show particularly well the changes in blood specific gravity as they are effected centrally by the stimulus of heat or cold applied to the basal ganglia; or from changes effected by puncture alone.

$$
\begin{aligned}
\text { Ordinates - } & \text { Upper lines represent blood specific } \\
& \text { gravity. } \\
& \text { Lower lines represent rectal temperature } \\
& \text { in }{ }_{\mathrm{F} .}
\end{aligned}
$$

Abscissae - Time in hours.

Figures I, II and III are from rabbits having simple puncture with subsequent application of heat and cold to the basal ganglia.

Figure IV shows blood specific gravity and rectal temperature increase due to simple puncture. Puncture was made at time corresponding to position of the arrow.

Figures V, VI and VII show blood specific gravity and rectal temperature increase in rabits having liver artery with plexus severed; No. V after application of cold; Nos. VI and VII after cerebral puncture. 


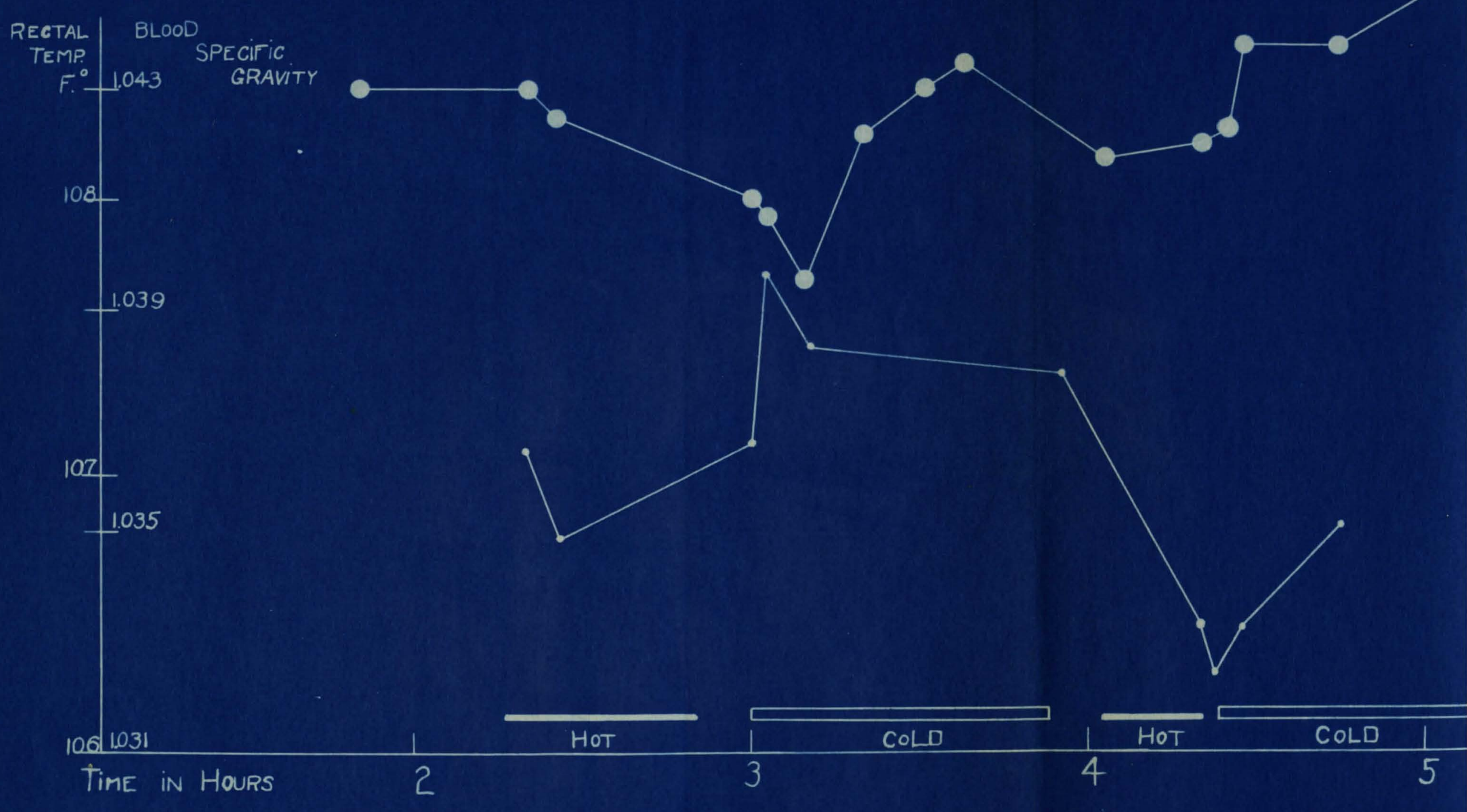

Fis. I 
TABIE II.

Experiment of 10-10-30. Effect of cooling and heating basal ganglia on blood concentration.

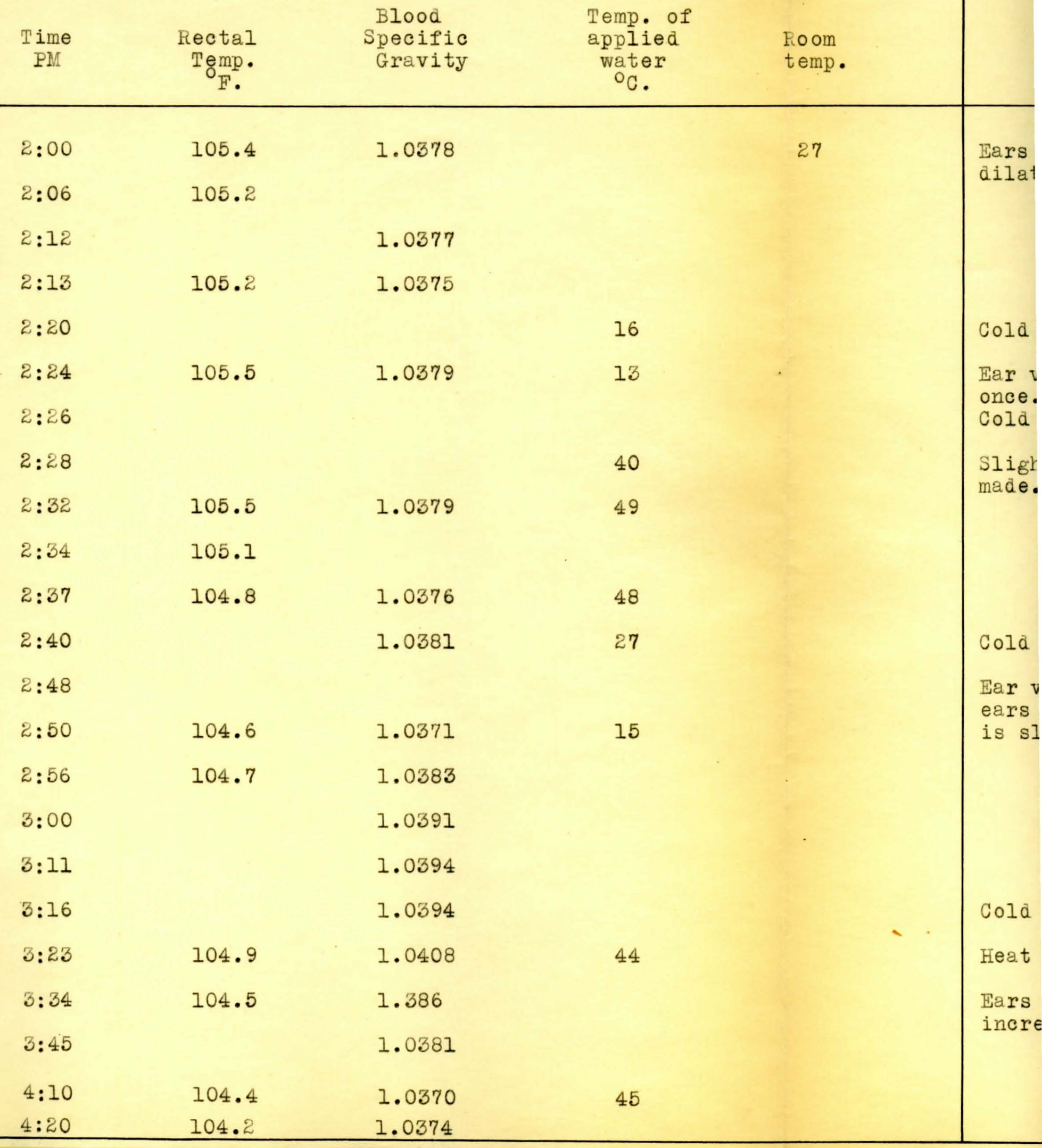




\begin{tabular}{l|l}
\hline $\begin{array}{l}\text { Rom } \\
\text { temp. }\end{array}$ & \multicolumn{1}{|c}{ REMARKS } \\
\hline 27 & $\begin{array}{l}\text { Ears warm. Ear vessels moderately } \\
\text { dilated. }\end{array}$
\end{tabular}

Cold was applied.

Ear vessels were constricted at once. Ears becoming cold. cold removed.

Slightly active when change was made. Ears become warmer.

Cold applied.

Ear vessels constrict at once and ears become cold. Respiration is slower.

Cold off.

Heat on. Far vessels again dilate. Ears become warmer and respiration increases. 


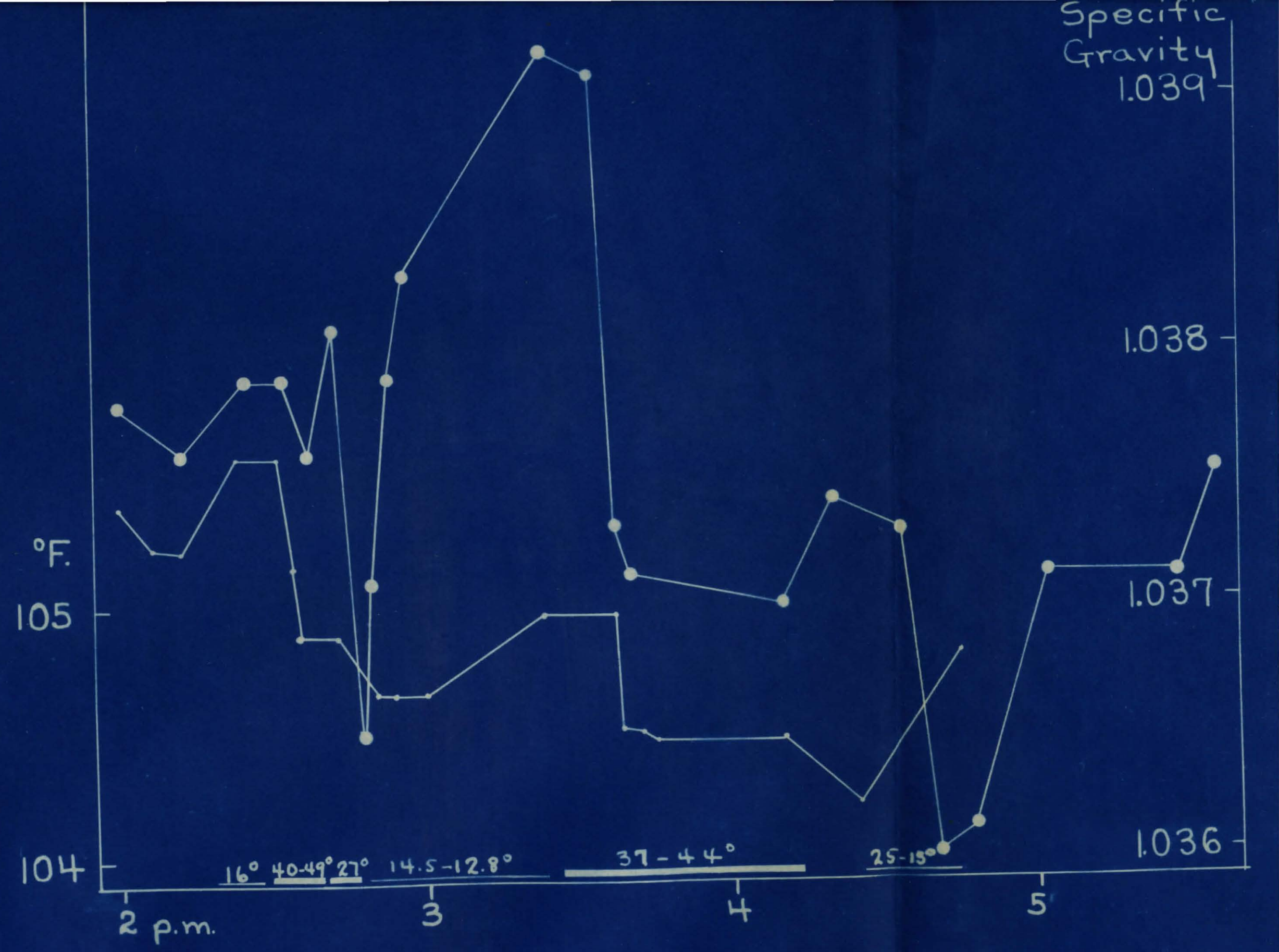

Fị̄. II 


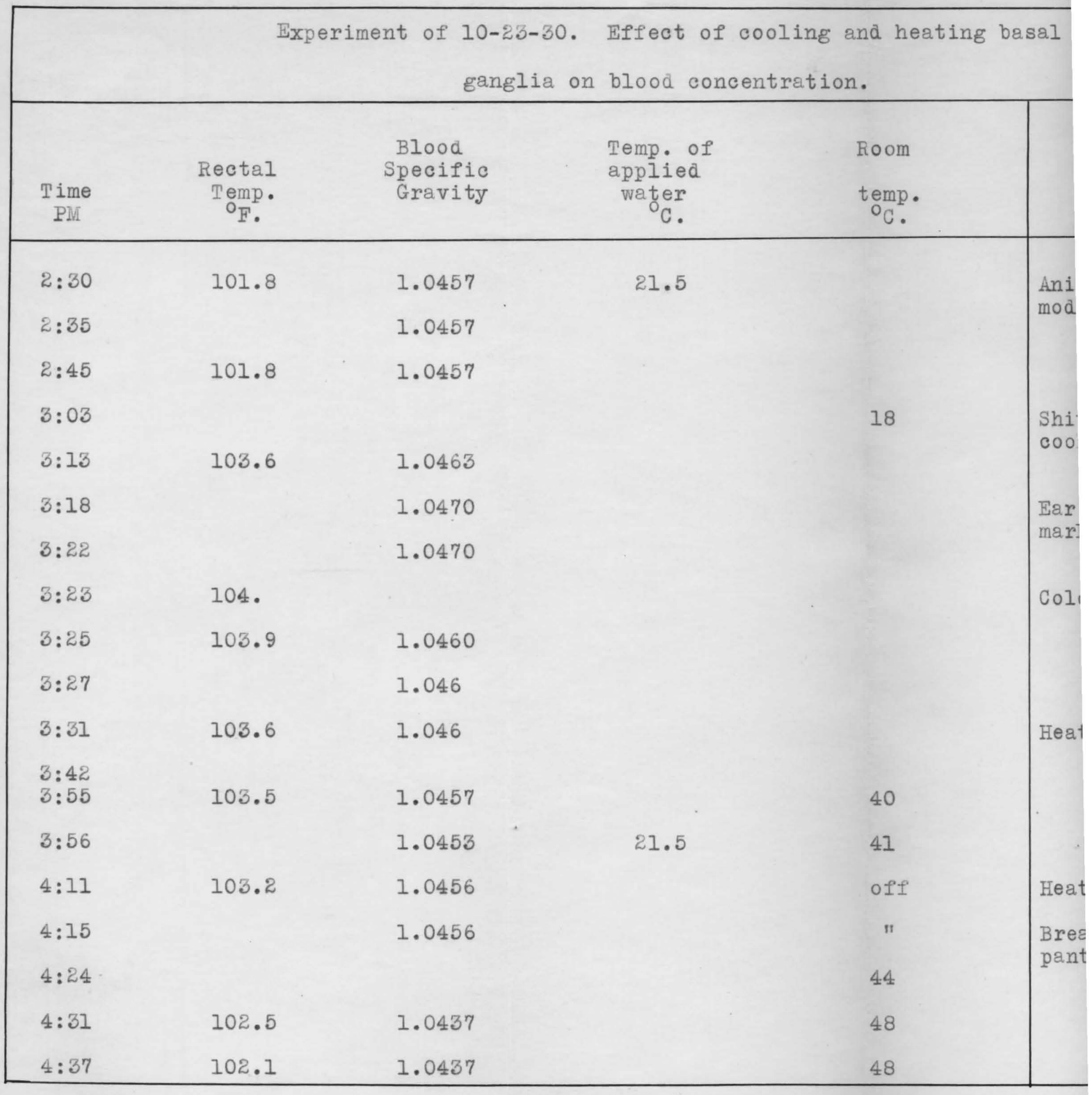


d heating basal

REMARKS.

Animal normal, flow good, ears moderately warm.

Shivering in jaw after 5 minutes of cooling basal ganglia.

Ear vessels constricted. Blood flow markedly reduced.

Cold off.

Heat on.

40

41

off

Heat off.

Breathing very much accelerated to panting rate. Ear vessel very dilated. 


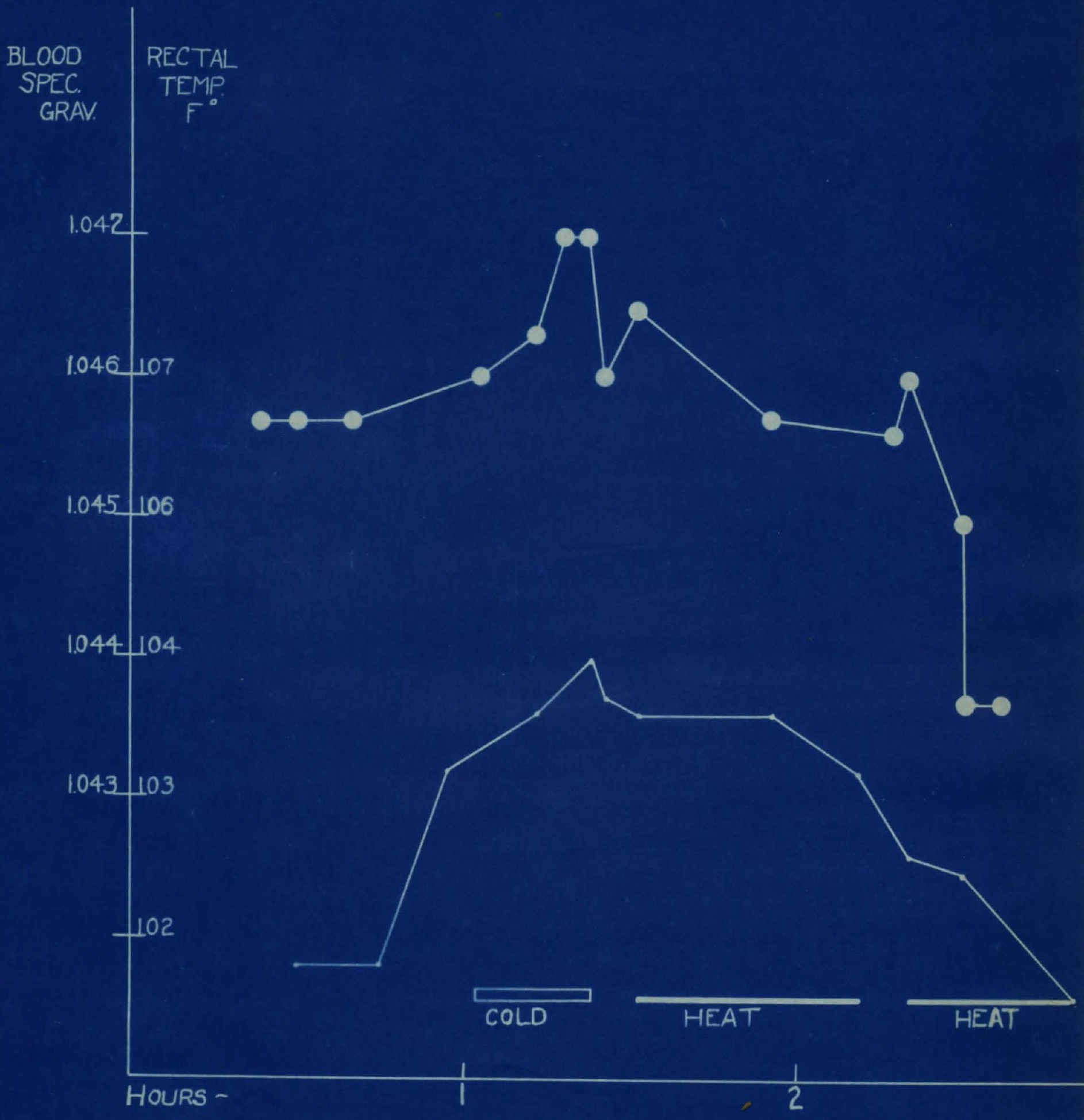

Fi \&. III 
the preceding experiment (see Table II, Figure II).

October 23,1930. Rabbit No. 6, a Flemish male rabbit weighing $2810 \mathrm{gms}$. , in good condition. This rabbit was operated on as before at 9:30 AM and puncture made at 10:00 AMl. A good recovery was effected by 1:00 PM; at 2:30 PM rectal temperature was $101.8^{\circ} \mathrm{F}$. and remained thus until $2: 45$ with the blood specific gravity at 1.0457 . At 3:03 PM the rectal temperature was $103.2^{\circ} \mathrm{F}$ evidencing a good puncture fever; the blood specific gravity was 1.046 . Cold was then applied to the basal ganglia and at 3:23 rectal temperature had increased to $104.0^{\circ} \mathrm{F}$. and the blood specific gravity had increased to 1.047 . Cold was removed and here again the heat stimulus was evidenced. When heat was applied at $3: 42 \mathrm{PM}$, a drop occured in rectal temperature to $101.6^{\circ} \mathrm{F}$. by $4: 50 \mathrm{PM}$ with the blood concentration reduced to 1.0437 . 
TABLE IV.

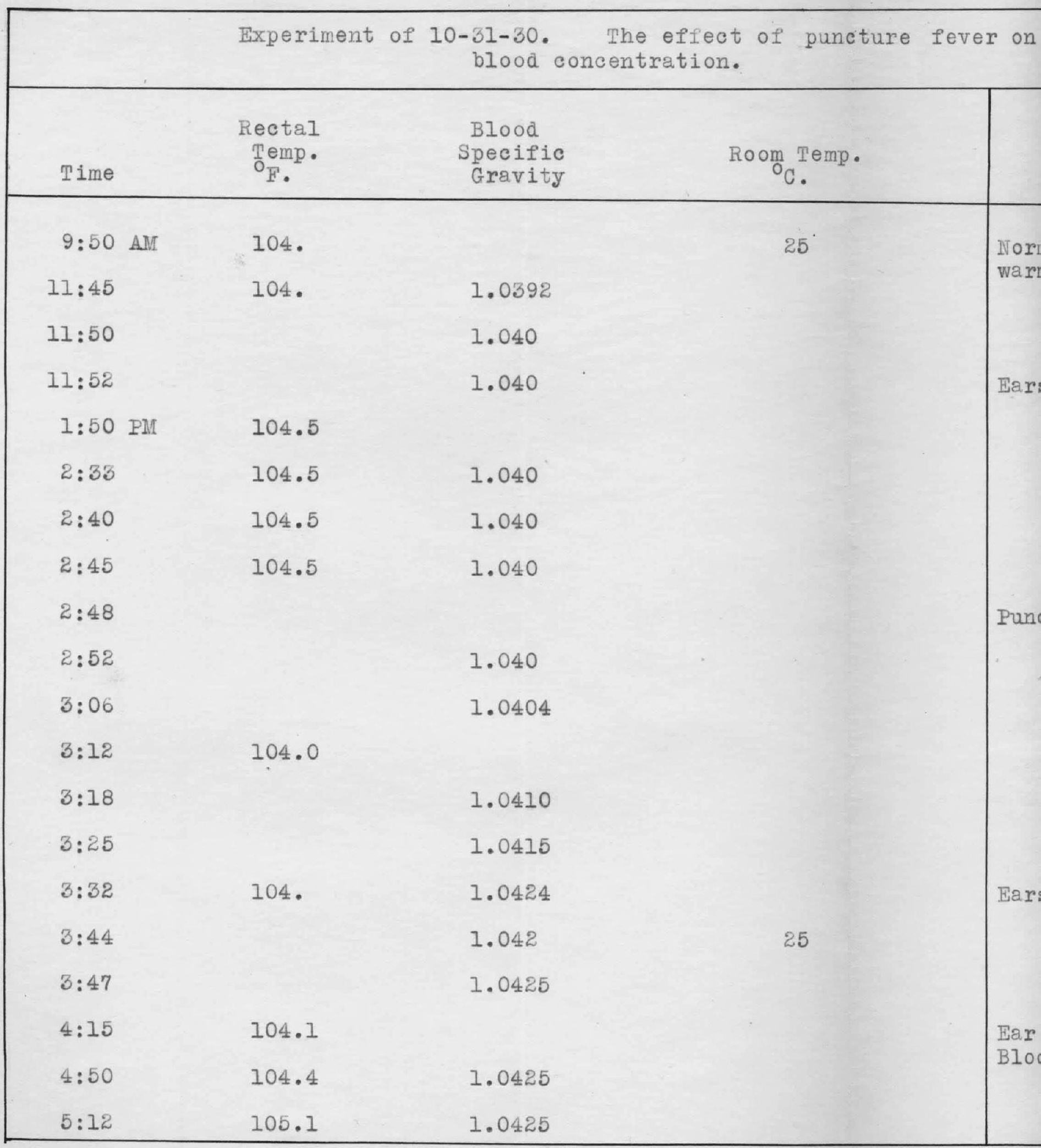


ture fever on

REMARKS

Normal animal, not excited. Ears warm.

Ears still warm. Blood flow is good.

Puncture was made.

Ears cooler.

Ear vessels are now constricted. Blood flow is much slower. 


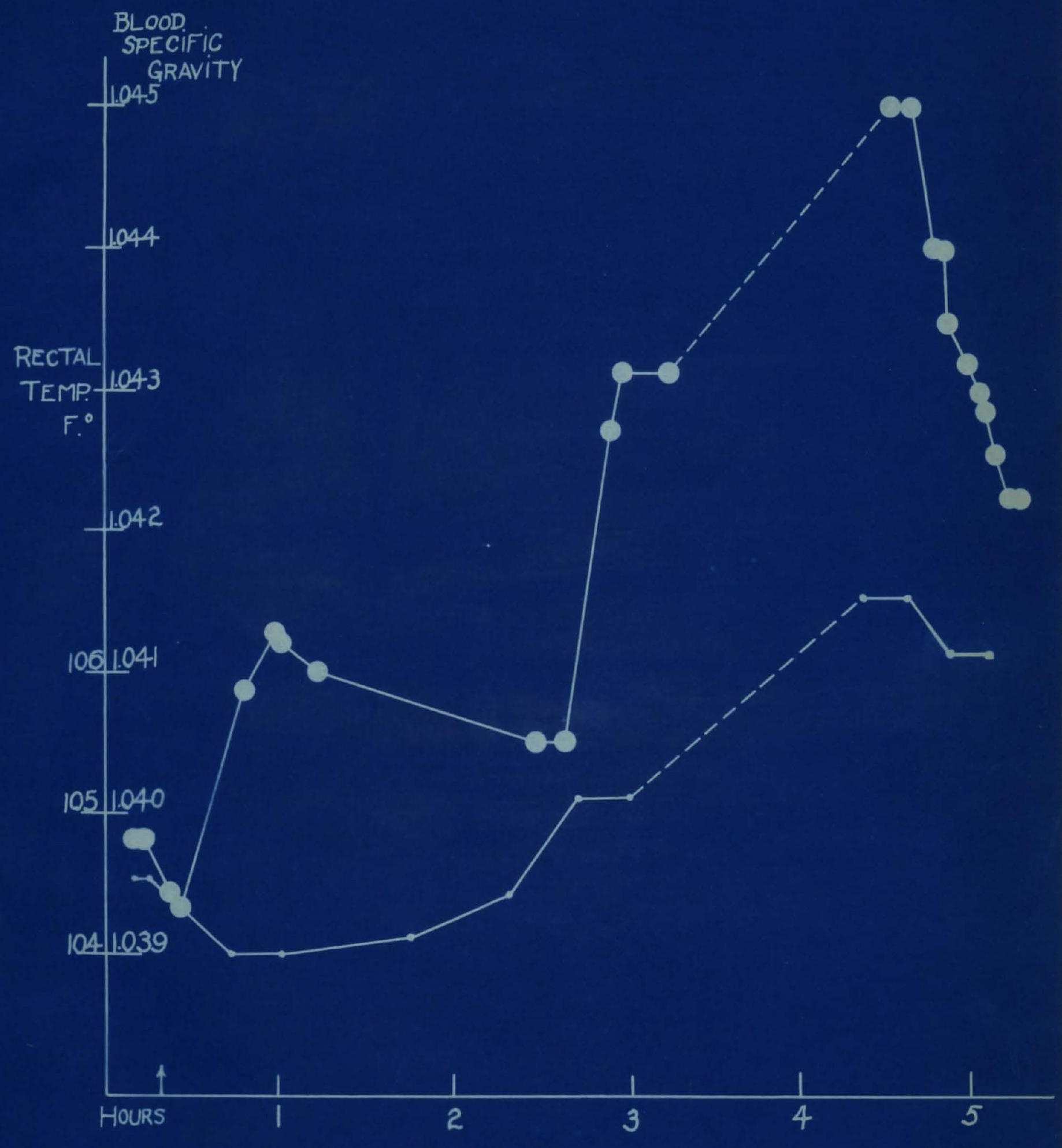

Fis. IV 
Investigations of Blood Concentration in Heat Puncture and "Cold Fever" Supplemented by the Contrasted Effects of Heating the Basal Ganglia in Rabbits with the Hepatic Artery and its Plexus Cut. 
Investigations of Blood Concentration in Heat Puncture and "Cold Fever" Supplemented by the Contrasted Effects of Heating the Basal Ganglia in Rabbits with the Hepatic Artery and its Plexus Cut.

Procedure.

For the abdominal operations larger rabbits were used than in the first group experiments. The same technique used in the previous series of experiments was used for the heat puncture here and the method of denervating the liver was that used by Plant (14) et al, in their metabolism and body heat regulation experiments. All operations were done under ether. The abdomen, like the head, was shaved clean of hair and a mid line incision of approximately $10 \mathrm{~cm}$ was made extending caudal from the xyphoid process. Care was taken in unnecessarily handling the intestine by packing the viscera to the right side and below with sterile gauze sponges saturated in warm sterile saline. The left vagus was sought as it entered the abdomen and this was drawn forward and down to reveal any branches which might be given off to the right, these were cut. leaving vagus to the stomach intact. The hepatic artery was then freed from the portal vein, doubly lighted with its plexus and cut. Adjacent strands of fatty and connective tissue were examined for possible stray nerve fibers. There was no ap- 
preciable loss of blood in any of the animals operated on and recovery was realized in seventy-five percent of the number operated on. 
The Method of Heating and Cooling the Basal Ganglia in the Liver Denervated Rabbits was the same as in the Simple Puncture Ones and All Other Procedures Were the Same.

\section{Observations.}

November 19,1930 , rabbit No. 11 , a normal Flemish female rabbit weighing 2750 gms. was operated on at 9:15 AM and the liver denervated. Rectal temperature at time of operation was 103.1 $1^{\circ}$ F. November 20th at 10:00 AM rectal temperature was $103.5^{\circ} \mathrm{F}$, operated at 10:30 for heat puncture; puncture was made at time of operation. At 1:00 PM the rabbit was nicely recovered, posture normal, head and ears normal, movements coordinated; at 2:48 PM rectal temperature was $104.4^{\circ} \mathrm{F}$. , blood specific gravity was 1.0479 . There was no change in the specific gravity of the blood beyond experimental error during the development of fever nor during the period of cold applied on the basal ganglia - less fever developed and at a slower rate than in the unoperated punctures. After 4 hours and 25 minutes the specific gravity of the blood had not varied beyond the allowed limit - the lowest specific gravity 1.0477 , the highest 1.0479. The rectal temperature had increased to $105.5^{\circ}$ F. (See Table V).

December 12,1930, a Flemish male rabbit weighing $2250 \mathrm{gms.,}$ was operated on at 10:15 AM. Liver denervation and cranial 
TABLE V.

\section{Experiment of 11-20-30. The effect of cooling of rabbit with denervated liver.}

\begin{tabular}{|c|c|c|c|c|}
\hline Time & $\begin{array}{c}\text { Rectal } \\
\text { Temp. } \\
\mathrm{O}_{\mathrm{F}} .\end{array}$ & $\begin{array}{l}\text { Blood } \\
\text { Specific } \\
\text { Gravity }\end{array}$ & $\begin{array}{c}\text { Temp. of } \\
\text { applied } \\
\text { water } \\
{ }^{\circ} \mathrm{C} .\end{array}$ & $\begin{array}{l}\text { Roor } \\
\text { tem] }\end{array}$ \\
\hline $\begin{array}{l}\text { Nov. } 19 \\
9: 15 \text { AM } \\
\text { Nov. } 20 \\
10: 30 \mathrm{AM}\end{array}$ & 103.1 & & & 25 \\
\hline 1:00 PM & 104.0 & & & \\
\hline $2: 48$ & 104.4 & 1.0479 & & \\
\hline $3: 00$ & 104.4 & 1.0479 & & \\
\hline $3: 08$ & 104.4 & 1.0479 & & \\
\hline $3: 20$ & 104.4 & 1.0479 & & \\
\hline $3: 31$ & 104.4 & 1.0479 & & \\
\hline $3: 35$ & & & 22 & \\
\hline $3: 40$ & 105.1 & & 18 & 25 \\
\hline $3: 42$ & & 1.0478 & & \\
\hline $3: 52$ & . & 1.0478 & 18 & \\
\hline $3: 58$ & 105.1 & 1.0479 & 18 & \\
\hline $4: 16$ & 105.1 & & & \\
\hline $4: 23$ & & 1.0478 & & \\
\hline $4: 32$ & & 1.0479 & & \\
\hline $4: 40$ & & 1.0479 & & \\
\hline $4: 47$ & 105.5 & ze & & \\
\hline $4: 52$ & 105.0 & 1.0478 & & \\
\hline $4: 55$ & & 1.0477 & & \\
\hline
\end{tabular}




\section{REMARKS}

Puncture operation and puncture done at the same time.

Blood flow was relatively good. Ears warm.

Cold water was applied.

Ear vessels constricted.

Ears become cold and blood flow is slow.

Cold removed.

Vaso constriction is relieved and ears become warmer.

Blood flow is maintained well, ears remain warm. 


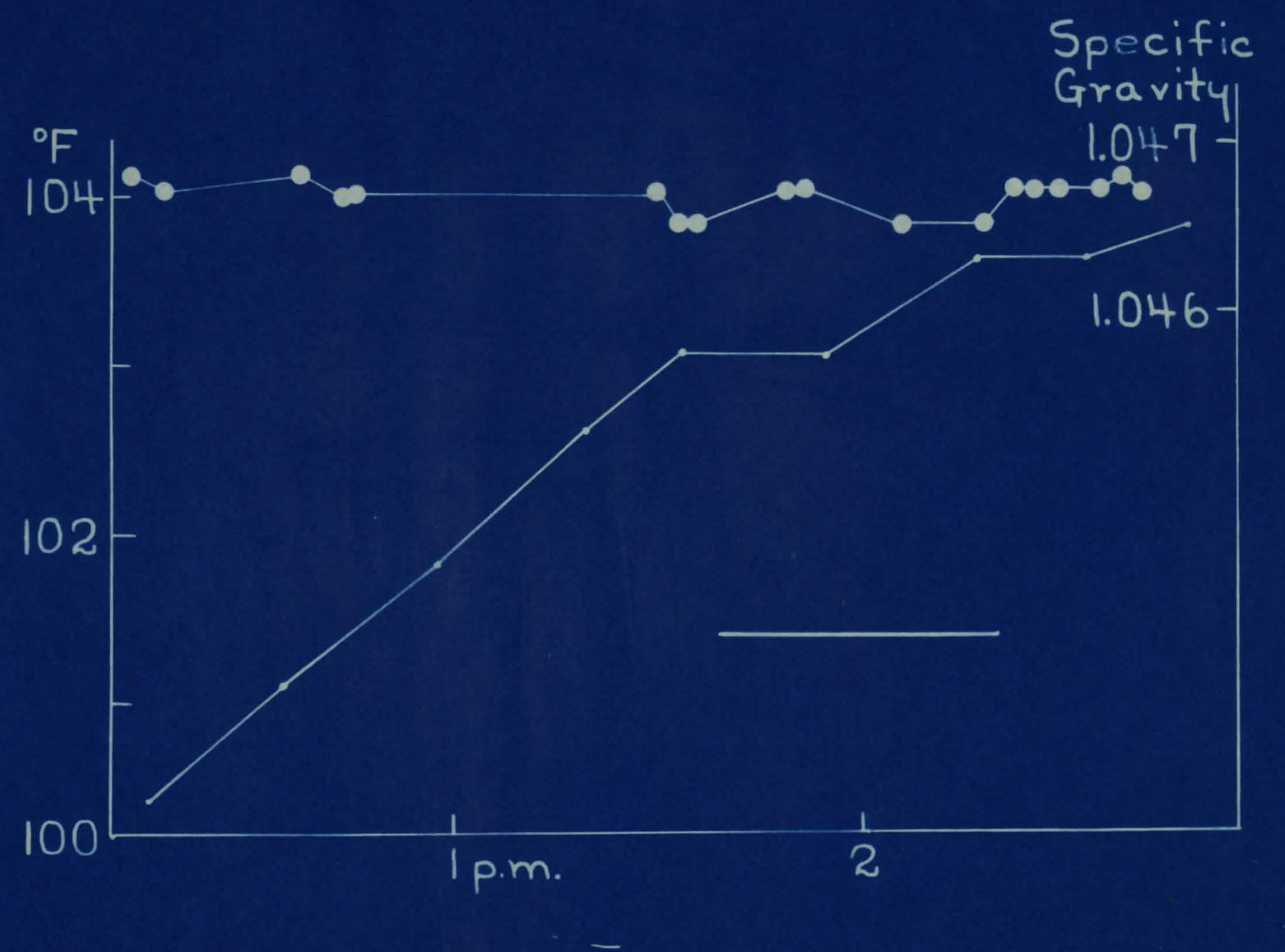

Fis. V 
puncture was done as before except that puncture was made at time of operation for denervation. From 1:23 Pui until 3:57 PM rectal temperature rose from $100.2^{\circ} \mathrm{F}$. to $103.8^{\circ} \mathrm{F}$. The highest blood specific gravity was 1.0459 , the lowest 1.0454 with only one determination at lowest and that was taken two minutes after shutting off of cold. When the cold was applied vaso constriction occured, respiration became slower and ears were cold; on removal of cold stimulus the vasomotor response was that of the unoperated rabbit with return of some dilatation in ear vessels; accelerated breathing and ears warm with body outstretched (see Table VI, Fig. V).

December 18, 1930 a non-pregnant Flemish female weighing $4450 \mathrm{gms}$. was operated at 10:45 AM. Liver denervation and heat puncture were done; temperature at time of operation, $102.2^{\circ}$ F. The animal recovered well but had low rectal temperature at 1:30 of $98.6^{\circ} \mathrm{F}$. There was evidence of lung edema of severe nature at that time and the blood specific gravity was 1.0435 . There was a shivering in the jaw muscles, ears relatively cold but the vessels were partly dilated. At 4:00 PM the rectal temperature was $99.9^{\circ} \mathrm{F}$. and blood specific grevity had decreased, the lung edema had improved. At 5:10 PM the rectal temperature had reached $100.4^{\circ}$ F., blood specific gravity was 1.0412 - the lung edema was further improved. On December 19th at 10:45 AM 
TABIE VI.

\begin{tabular}{|c|c|c|c|c|}
\hline & & $\begin{array}{l}\text { riment of } 12-11 \\
\text { basal ganglia }\end{array}$ & $\begin{array}{l}\text {-30. The effect } \\
\text { of rabbit having }\end{array}$ & $\begin{array}{l}\text { of heating and } \\
\text { denervated live }\end{array}$ \\
\hline $\begin{array}{c}\text { Time } \\
\text { PM }\end{array}$ & $\begin{array}{l}\text { Rectal } \\
\text { Temp. } \\
\text { ô. }_{\mathrm{F}}\end{array}$ & $\begin{array}{l}\text { Blood } \\
\text { Specific } \\
\text { Gravity }\end{array}$ & $\begin{array}{c}\text { Temp. of } \\
\text { applied } \\
\text { water } \\
{ }_{\mathrm{C}} \text {. }\end{array}$ & $\begin{array}{l}\text { Room } \\
\text { Temp. } \\
\text { OF. }\end{array}$ \\
\hline $1: 23$ & 100.2 & 1.0459 & & $25: 5$ \\
\hline $1: 26$ & . & 1.0458 & & \\
\hline $1: 47$ & & 1.0459 & & \\
\hline $1: 50$ & 101.1 & & & \\
\hline $1: 54$ & & 1.0458 & & \\
\hline $2: 15$ & & 1.0459 & & \\
\hline $2: 17$ & 101.8 & & & \\
\hline $2: 34$ & 102.6 & & & \\
\hline $2: 41$ & & 1.0458 & & \\
\hline $2: 46$ & & 1.0456 & on & \\
\hline $2: 58$ & & & 20 & \\
\hline $3: 01$ & & 1.0458 & 14 & \\
\hline $3: 04$ & & 1.0458 & 13 & \\
\hline $3: 08$ & 103.1 & & & \\
\hline $3: 33$ & 103.6 & 1.0458 & & \\
\hline $3: 36$ & & & off & 26 \\
\hline $3: 42$ & & 1.0458 & & \\
\hline $3: 52$ & & 1.0458 & & \\
\hline $3: 55$ & & 1.0459 & & \\
\hline $3: 57$ & & 1.0458 & & \\
\hline $4: 00$ & 103.8 & & & \\
\hline
\end{tabular}


and cooling

a liver.

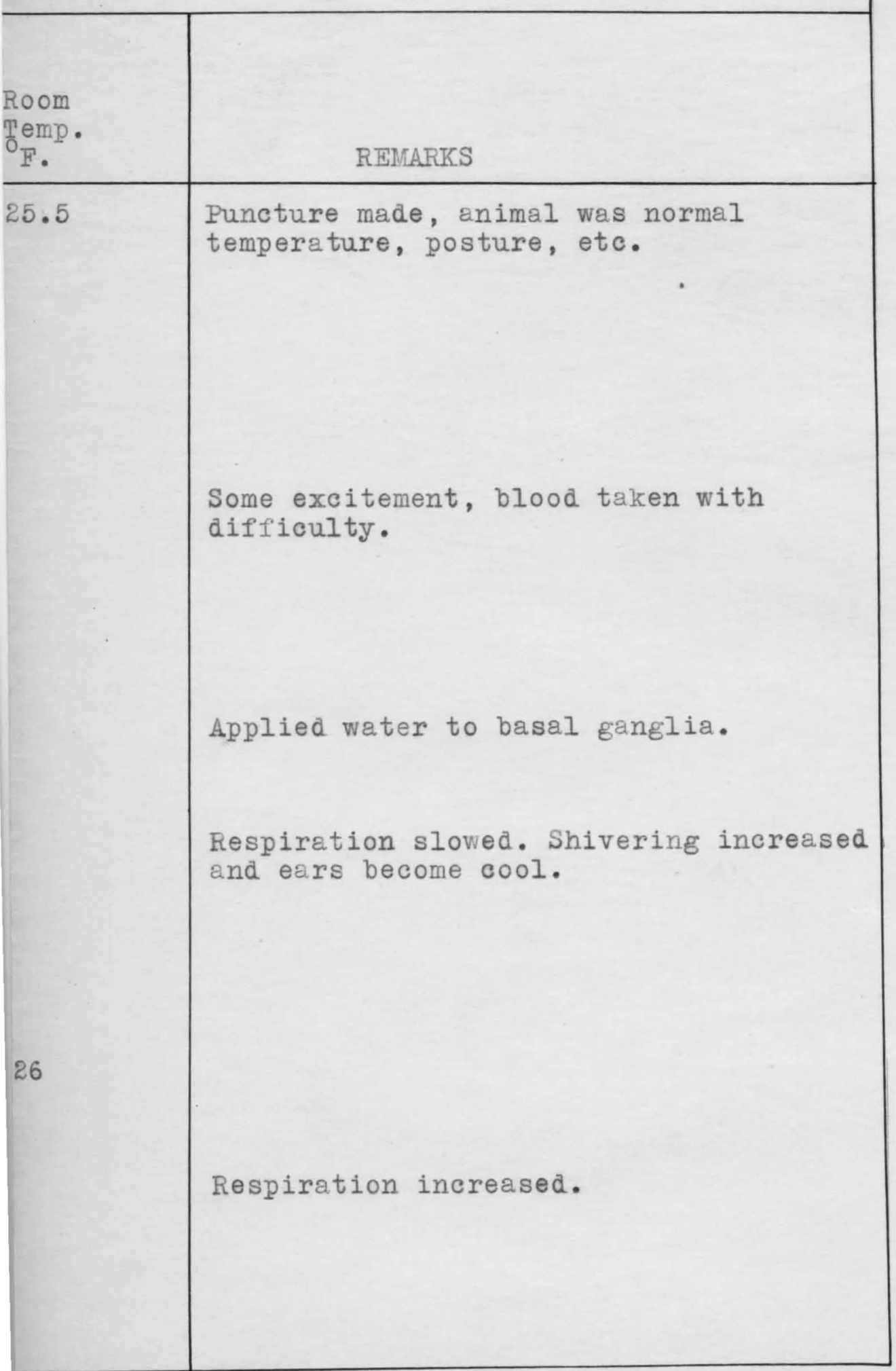


TABIE VII.

\begin{tabular}{|c|c|c|c|}
\hline & \multicolumn{3}{|c|}{$\begin{array}{c}\text { Experiment of 2-11-31. The effect of puncture } \\
\text { having denervated liver. }\end{array}$} \\
\hline$\underset{\text { PM }}{\text { Time }}$ & $\begin{array}{l}\text { Rectal } \\
\text { Temp. } \\
\text { of }\end{array}$ & $\begin{array}{l}\text { Blood } \\
\text { Specific } \\
\text { Gravity }\end{array}$ & $\begin{array}{l}\text { Room Temp. } \\
{ }^{\circ} \mathrm{C} \text {. }\end{array}$ \\
\hline $1: 56$ & 104.0 & 1.0486 & 26 \\
\hline $2: 11$ & 103.6 & 1.0486 & \\
\hline $2: 13$ & & 1.0496 & \\
\hline $2: 17$ & & 1.0496 & \\
\hline $2: 20$ & 103.6 & & \\
\hline $2: 25$ & & & 26 \\
\hline $2: 38$ & 105.1 & & \\
\hline $2: 40$ & & 1.0491 & \\
\hline $2: 45$ & & 1.0495 & \\
\hline$\dot{2}: 47$ & & 1.0494 & \\
\hline $2: 53$ & & 1.0494 & \\
\hline $2: 57$ & & 1.0497 & \\
\hline $3: 11$ & 105.5 & 1.0495 & \\
\hline $3: 18$ & 106.3 & & \\
\hline $3: 19$ & & 1.0496 & \\
\hline $3: 39$ & 106.3 & & \\
\hline $3: 50$ & & 1.0496 & \\
\hline $3: 55$ & & 1.0498 & \\
\hline $3: 58$ & 107.2 & & \\
\hline $4: 15$ & 107.5 & 1.0497 & 26 \\
\hline $4: 30$ & 707.6 & & \\
\hline
\end{tabular}


Movements normal; ears relatively cool but blooa flow is good.

Very quiet on table; resumes normal posture after temperature readings.

Puncture was made.

No resistance to handing when taking temperature.

Ears cold; circulation slow.

Posture still good.

Reflex is present, ears are still cold.

Ho shivering apparent at any time. 


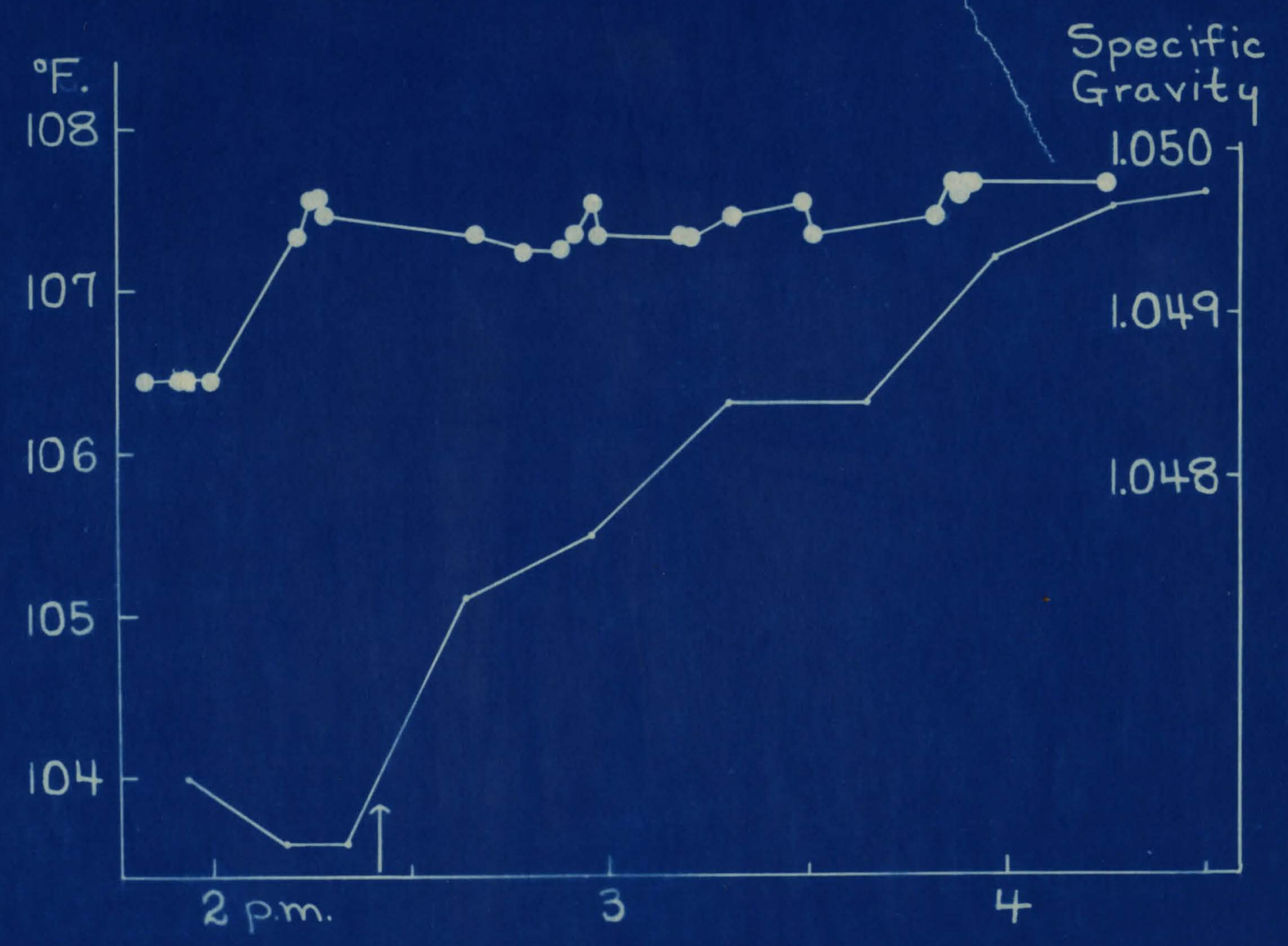

Fig. VI 


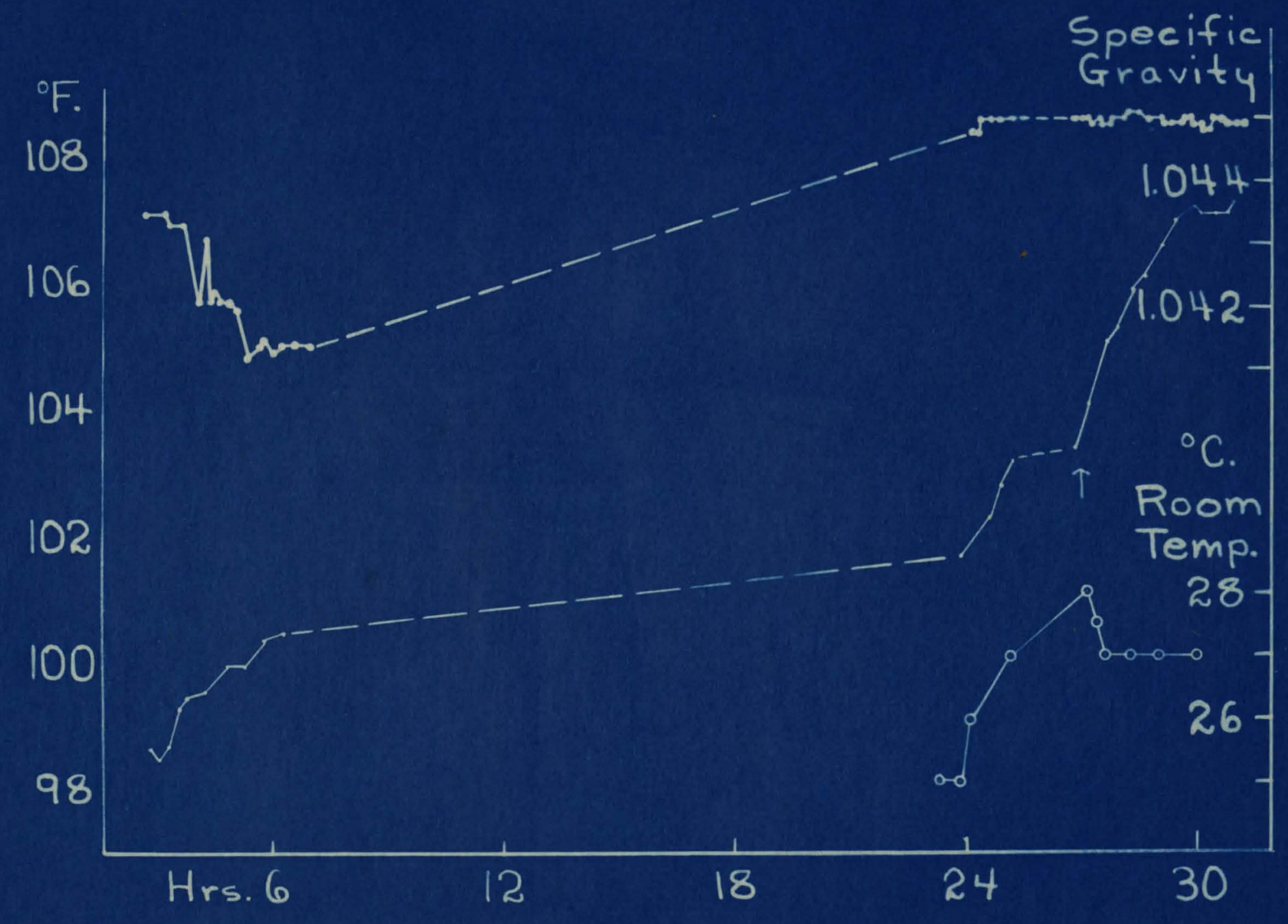

Fis. V11 
the blood specific gravity was 1.0448 , rectal temperature $101.6^{\circ} \mathrm{F}$. At $11: 45$ AM the rectal temperature was $103.1^{\circ} \mathrm{F}$. and the blood specific gravity was 1.045. The lung edema had entirely disappeared over night and the blood had concentrated. At 1:07 PM the blood specific gravity was 1.045 and the rectal temperature $103.3^{\circ} \mathrm{F}$. Puncture was made at 1:10 PM, temperature increased then to $107.2^{\circ} \mathrm{F}$. at $4: 28 \mathrm{PM}$ with specific gravity at 1.0449 having fluctuated only .0002 during the three hours and a half (see Fig. VI).

February 11th, a male New Zealand rabbit weighing 1765 gms. and in good condition was operated at 10:00 All. Liver denervation and insertion of plug in skull for puncture were done at 1:50 PM, rectal temperature was $104 .^{\circ} \mathrm{F}$, blood specific gravity 1.0486; at 2:15 PM rectal temperature was $103.6^{\circ} \mathrm{F}$. with blood specific gravity 1.0497. At 2:25 PM the puncture was made after which there was no significant change in blood specific gravity, although the temperature rose to $107.6^{\circ} \mathrm{F}$. which is a good puncture fever. (See Table VII, Fig. VII).

The influence of ether on blood concentration was investigated in these rabbits and the results are seen in Fig. VIII. The blood concentration resulting from the anesthetic approximates the higher blood specific gravity of the denervated rabbits which fact indicates that the denervation interferes with 
Legend to Figure VIII.

This figure shows the effect of ether anesthesia on the blood concentrations in three normal rabbits. Solids from the livers were obtained from these and the results are given in Table XII. Two of the rabbits having been allowed to recover to their normal condition. Ordinates - The blood specific gravity. Abscissae - The time in hours; duration of ether administration. 
BLOOD

SPECIFIC
GRAVITY

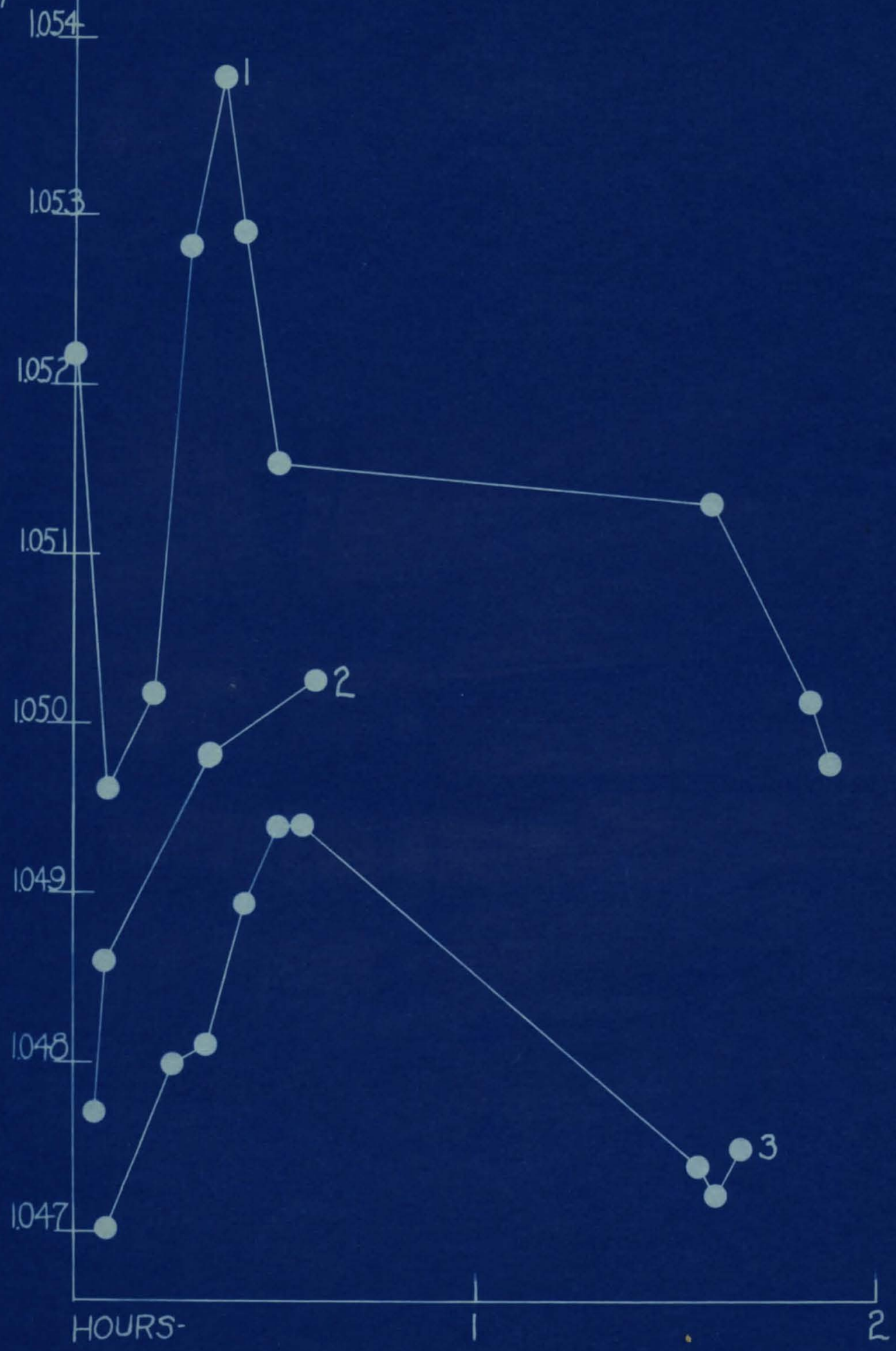

Fis. VIII 
dilution of the blood after concentration from ether. The effects of liver denervation on rate of febrile temperature rise are seen in Fig. IX which was constructed from experiments on six rabbits chosen at random from the above. This figure shows a decrease in rate of febrile temperature rise after denervating the liver. However, the impairment does not seem to be contingent on the water shifting alone as is revealed in the individual experiments. 
TABLE VIII

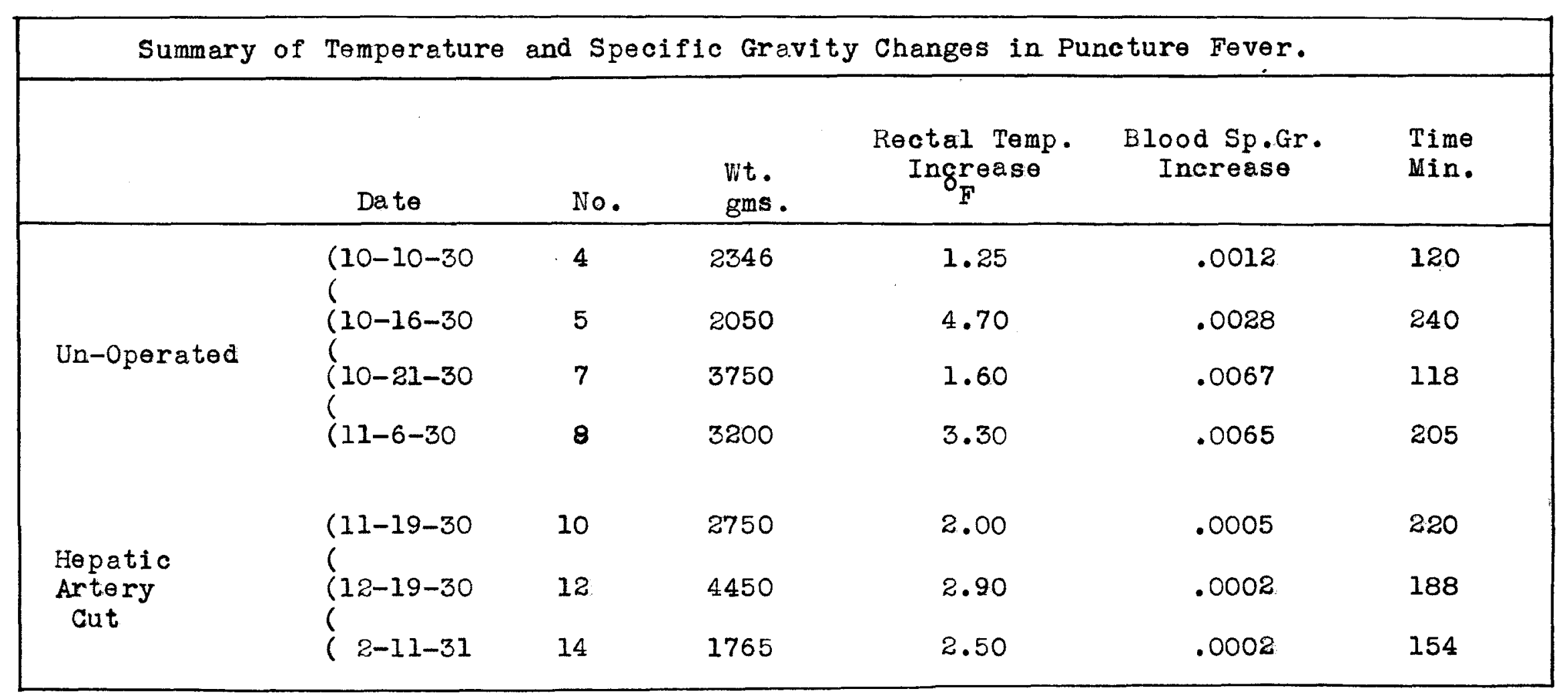


Legend to Figure IX.

The relationship of the rate of febrile temperature rise to the procedure used in experimentation is shown in this figure. The solid lines represent the temperature rise in three simple puncture rabbits and the broken lines represent the rise of temperature in three puncture rabbits which have had their hepatic arteries with plexus cut. In both procedures fever was induced by cooling the basal ganglia.

$$
\begin{gathered}
\text { Ordinates - Rectal temperature in }{ }^{\circ} F \\
\text { Abscissae - Time in hours after application of cold } \\
\text { stimulus to the basal ganglia. }
\end{gathered}
$$




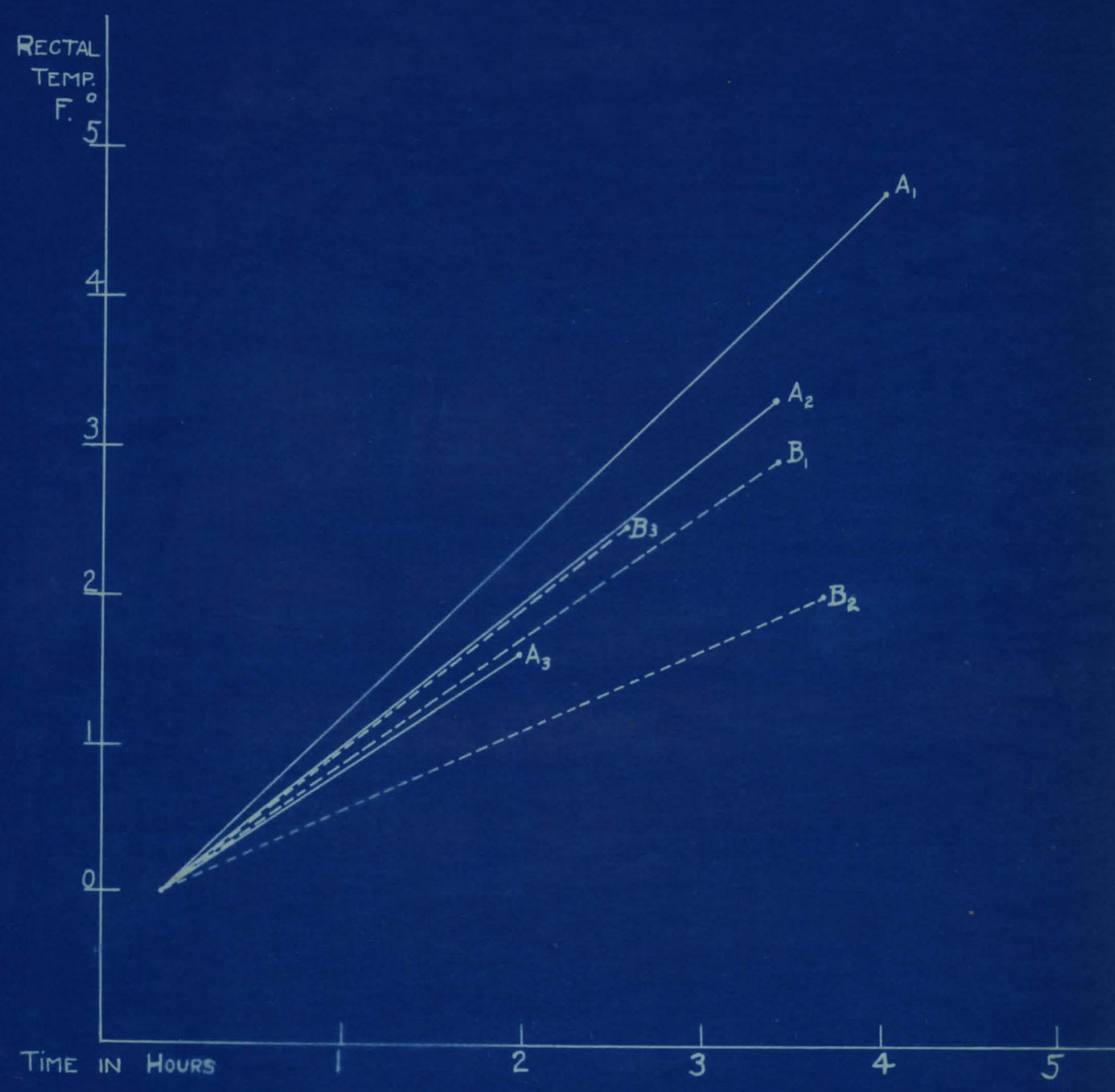

Fi $8.1 X$ 
DISCUSSION 


\section{Discussion.}

Blood concentration is induced by puncture of the brain and by cooling the basal ganglia; conversely a blood dilution is induced by heating the basal ganglia, but neither of these changes occur when the hepatic artery with its plexus is severed.

It is evident however, that the blood of the rabbits thus denervated is more concentrated than that of the unoperated ones, a condition which may be assumed to result originally from etherization which does cause a marked blood concen-. tration in unoperated rabbits as shown in Fig. VIII. This ether concentration of the blood is not enduring in normal rabbits and dilution on withdrawal of ether gives the blood its normal concentration within an hour of withdrawing the ether. In the liver denervated rabbits there is no return of the blood to normal concentration after operative procedure which may be due in part to a lowered condition of a saturation in the liver as well as to the interference with the nervous control of the water shifting mechanism.

The rate of body temperature increase in fever is not greatly affected by denervation of the liver, although it is somewhat reduced. In as much as the vasomotor ear responses are present in both types of experimental animals, it is evident 
that the vasomotor portion of the heat regulating mechanism is undisturbed.

The blood concentration in the neurogenic fevers we have described if due to removal of water from the blood to the liver would be accompanied by reduction of liver solids. The condition then would be comparable to that described by Lamson (16) wherin fluid escaped from the blood into the liver. The remainder of our work to be herein described bears upon this possibility. 
INVESTIGATIONS OF THE LIVER AS A LECHANISM FOR CONTROL OF BLOOD CONCENTRATION. 
Investigations of the Liver as Hechanism for Control of Blood Concentration.

To learn how liver water was influenced by the operative procedures described in the first part of this work, offered the next objective. Were the liver solids reduced? If so, in what manner was the fluid held in the liver, as fluid engorging the liver lymphatics or as fluid taken up by the liver cells?

It has been known for a long time (1) that after cutting the hepatic artery under ether anesthesia microscopic studies of the liver cells revealed them to be three or four times the size of normal liver cells. Also that the glycogen decreases in percent and the cells appear heavily laden with fluid; granulation in the cytoplasm is of smaller sized particles and chiefly centered adjacent to the nucleus which still retains its normal appearance.

Nothing however has been known with regard to the effects of external cold upon the liver water nor has it ever been shown to be influenced by procedures limited to the brain.

\section{Procedure.}

In order to minimize differences in liver solids due to age and dietary conditions, rabits of the same litter were used in the group experiments. Also the same methods and care in 
aseptic operative procedure was maintained; handling and routine treatment on the experimental table were observed as before.

Six normel New Zealand rabbits of the same litter were used for the experiment of February 24th. Their weight varied between 1230 and $1420 \mathrm{gms}$. However, all were in good condition and all had been given the same care and diet prior to the experiment. Two of the rabbits were used as controls; one was operated by heat puncture as before and three were operated by both cranial puncture and liver denervation. However, one of the rabbits, No. 20 , died on the operating table apparently from surgical shock. The other five made nice recoveries. All operations were done in the morning of the same day.

the rabbits were killed by a sharp blow at the base of the occiput and the head removed with large shears; the whole procedure requiring less than 30 seconds. The abdomen was opened at once and small pieces of liver approximately $0.5 \mathrm{gm}$. were obtained from the three large lobes. The samples were taken individually, placed on watch glasses and weighed the same way immediately on removal of the sample. After weighing, the samples were placed in an oven kept at $100^{\circ}-105^{\circ} \mathrm{C}$. for 36 hours after which time they were weighed each day until there 
was no further loss in weight.

\section{Results.}

Table No. IX was compiled from the first litter experiment and here it is shown that the puncture markedly decreased the liver solids while puncture with the liver denervated showed still further reduction of liver solids. The rabbit with puncture and subsequent cooling of basal ganglia showed only slight reduction of liver solids from the normal, despite the fact that a blood concentration from 1.0432 to 1.0453 was obtained during the cooling process. Since the samples were taken so long after the puncture it was possible that the liver had to some extent regained its normal solidwater balence (see Fig. X) and that any water decrease at all would be due to the cooling influence of the basal ganglia. Samples of liver were taken for sectioning using formalin as a preservative.

Another litter experiment was done March 3rd and loth on eight New Zealand rabbits of about the same weight and physical condition. The same methods were used as in the previous experiment. In this experiment the same relation is shown as before between normal brain puncture and denervated livers, but the rabbit punctured and with heating of basal ganglia shows a marked increase in liver solids above the simple puncture rabbit and greater than the average of the normal indicating that the 
TABLE IX.

Experiment of February 24,1931.

\begin{tabular}{|c|c|c|c|c|c|c|c|c|}
\hline Procedure & $\begin{array}{l}\text { wt. } \\
\text { gms. }\end{array}$ & $\begin{array}{c}\text { Rabbit } \\
\text { No. }\end{array}$ & $\begin{array}{r}\text { Live } \\
\% \\
\text { Rt.Lobe }\end{array}$ & $\begin{array}{l}\text { r Solids } \\
\text { Solids } \\
\text { M. Lobe }\end{array}$ & L. Lobe & $\begin{array}{l}\text { Rectal Temp. } \\
\text { at death } \\
\text { oF. }\end{array}$ & $\begin{array}{l}\text { Time of } \\
\text { death } \\
\text { after } \\
\text { puncture }\end{array}$ & REMARKS. \\
\hline & 1350 & 15 & 26.3 & 26.6 & 26.1 & 103.8 & & \\
\hline Normal & 1360 & 16 & 27.6 & 27.8 & 28.7 & 102.8 & & \\
\hline $\begin{array}{l}\text { Puncture } \\
\text { Puncture } \\
\text { Liver Art. } \\
\text { tied }\end{array}$ & 1420 & 18 & 24.6 & 24.7 & 24.3 & 105.9 & $\begin{array}{l}1 \mathrm{hr} \text {. } \\
45 \mathrm{~min} . \\
1 \mathrm{hr} \text {. } \\
45 \mathrm{~min} .\end{array}$ & $\begin{array}{l}\text { Normal posture, coora: } \\
\text { and vasomotor respone } \\
\text { Good recovery, vasomots } \\
\text { responses, ears cold, } \\
\text { constricted. }\end{array}$ \\
\hline $\begin{array}{l}\text { Puncture } \\
\text { with cool- } \\
\text { ing basal } \\
\text { ganglia for } \\
30 \text { min. }\end{array}$ & 1230 & 19 & 27.1 & 26.0 & 26.0 & 105.8 & $2 \mathrm{hrs}$. & $\begin{array}{l}\text { Normal posture and ser } \\
\text { vasomotor responses. }\end{array}$ \\
\hline
\end{tabular}


Experiment of March 3rd and loth, 1931.

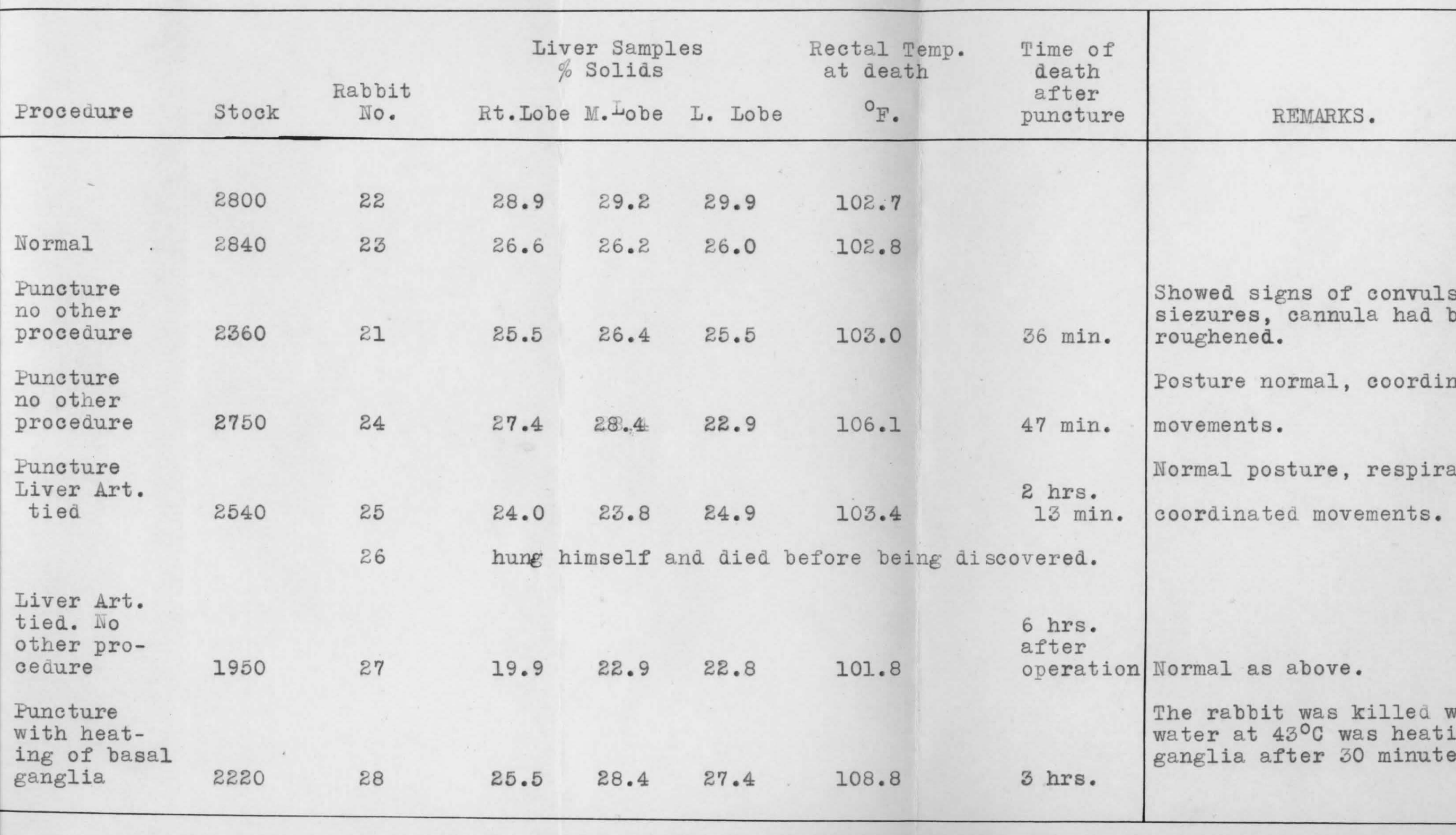




\begin{tabular}{|c|c|c|c|c|c|c|c|c|}
\hline Procedure & $\begin{array}{l}\text { wt. R } \\
\text { gms. }\end{array}$ & $\begin{array}{l}\text { bbit } \\
\text { No. }\end{array}$ & $\begin{array}{r}\text { Liv } \\
\text { Rt. Lobe }\end{array}$ & $\begin{array}{l}\text { er Soli } \\
\text { \% Solids } \\
\text { M.Lobe }\end{array}$ & ids & $\begin{array}{l}\text { Rectal Temp. } \\
\text { at death } \\
{ }^{\circ} \text { F }\end{array}$ & $\begin{array}{l}\text { Time of } \\
\text { death } \\
\text { after } \\
\text { puncture }\end{array}$ & Remarks \\
\hline & 2295 & 37 & 28.4 & 28.8 & 29.4 & 102.0 & & Killed 5:15 PM \\
\hline Normal & 2537 & 36 & 31.2 & 31.2 & 31.4 & 102.0 & & \\
\hline $\begin{array}{l}\text { Puncture } \\
\text { and heat- } \\
\text { ing basal } \\
\text { ganglia }\end{array}$ & 2125 & 32 & 27.2 & 28.0 & 28.2 & 103.6 & $\begin{array}{l}3 \text { hours } \\
5 \text { min. }\end{array}$ & $\begin{array}{l}\text { Posture and peripher- } \\
\text { al vasomotor responses } \\
\text { were normal. Treat- } \\
\text { ment } 35 \text { min. }\end{array}$ \\
\hline $\begin{array}{l}\text { Puncture } \\
\text { and cool- } \\
\text { ing basal } \\
\text { ganglia }\end{array}$ & 2020 & 33 & 27.1 & 26.7 & 25.9 & 102.6 & $\begin{array}{l}3 \text { hours } \\
45 \mathrm{~min} .\end{array}$ & $\begin{array}{l}\text { Normal posture re- } \\
\text { flexes and usual vaso- } \\
\text { motor responses. } \\
\text { Treatment for } 39 \text { min. }\end{array}$ \\
\hline $\begin{array}{l}\text { Puncture } \\
\text { and no } \\
\text { other } \\
\text { procedure }\end{array}$ & 2350 & 34 & 25.6 & 27.2 & 27.7 & 107.0 & $\begin{array}{l}5 \text { hours } \\
50 \text { min. }\end{array}$ & $\begin{array}{l}\text { Normal posture and } \\
\text { muscular coordination } \\
\text { ears relatively warm. }\end{array}$ \\
\hline & 1854 & 35 & 28.6 & 27.6 & 28.1 & 106.4 & $\begin{array}{l}5 \text { hours } \\
30 \mathrm{~min}\end{array}$ & $\begin{array}{l}\text { Normal posture and } \\
\text { muscular coordination } \\
\text { vasomotor responses, } \\
\text { ears warm. }\end{array}$ \\
\hline $\begin{array}{l}\text { Liver de- } \\
\text { nervation } \\
\text { Cranial } \\
\text { puncture } \\
\text { and cool- } \\
\text { ing basal } \\
\text { ganglia }\end{array}$ & 3524 & 40 & 17.7 & 23.1 & 23.5 & 102.1 & $\begin{array}{l}5 \text { hours } \\
25 \text { min. }\end{array}$ & $\begin{array}{l}\text { Puncture was made at } \\
\text { time of operation, re- } \\
\text { covery good, normal } \\
\text { posture and vaso- } \\
\text { motor responses. }\end{array}$ \\
\hline $\begin{array}{l}\text { Liver de- } \\
\text { nervation } \\
\text { Cranial } \\
\text { puncture } \\
\text { and heat- } \\
\text { ing basal } \\
\text { ganglia }\end{array}$ & 2967 & 41 & 27.4 & 21.0 & 21.4 & 106.5 & $\begin{array}{l}7 \text { hours } \\
30 \text { min. }\end{array}$ & $\begin{array}{l}\text { Puncture was made at } \\
\text { time of operation; } \\
\text { recovery good, normal } \\
\text { posture and vasomotor } \\
\text { responses. }\end{array}$ \\
\hline
\end{tabular}


Legend to Figure $X$.

This figure shows the relation of liver solids to the time which had elapsed following cerebral puncture.

Each liver solids figure represents the average of three solids determinations from each individual. The first figure was taken from normal rabbits having had no operative procedure.

$$
\begin{array}{ll}
\text { Figure } \mathrm{Xa} \text { - } & \text { Liver solids from rabbits having had } \\
& \text { only simple puncture. } \\
\text { Figure Xb - } & \text { Liver solids from rabbits having had } \\
& \text { liver denervated by method previously } \\
& \text { described. } \\
\text { Ordinates - } & \text { Fiver solids. } \\
\text { Abscissa - } & \text { Time in hours which elapsed from time } \\
& \text { of puncture to taking of liver samples. }
\end{array}
$$




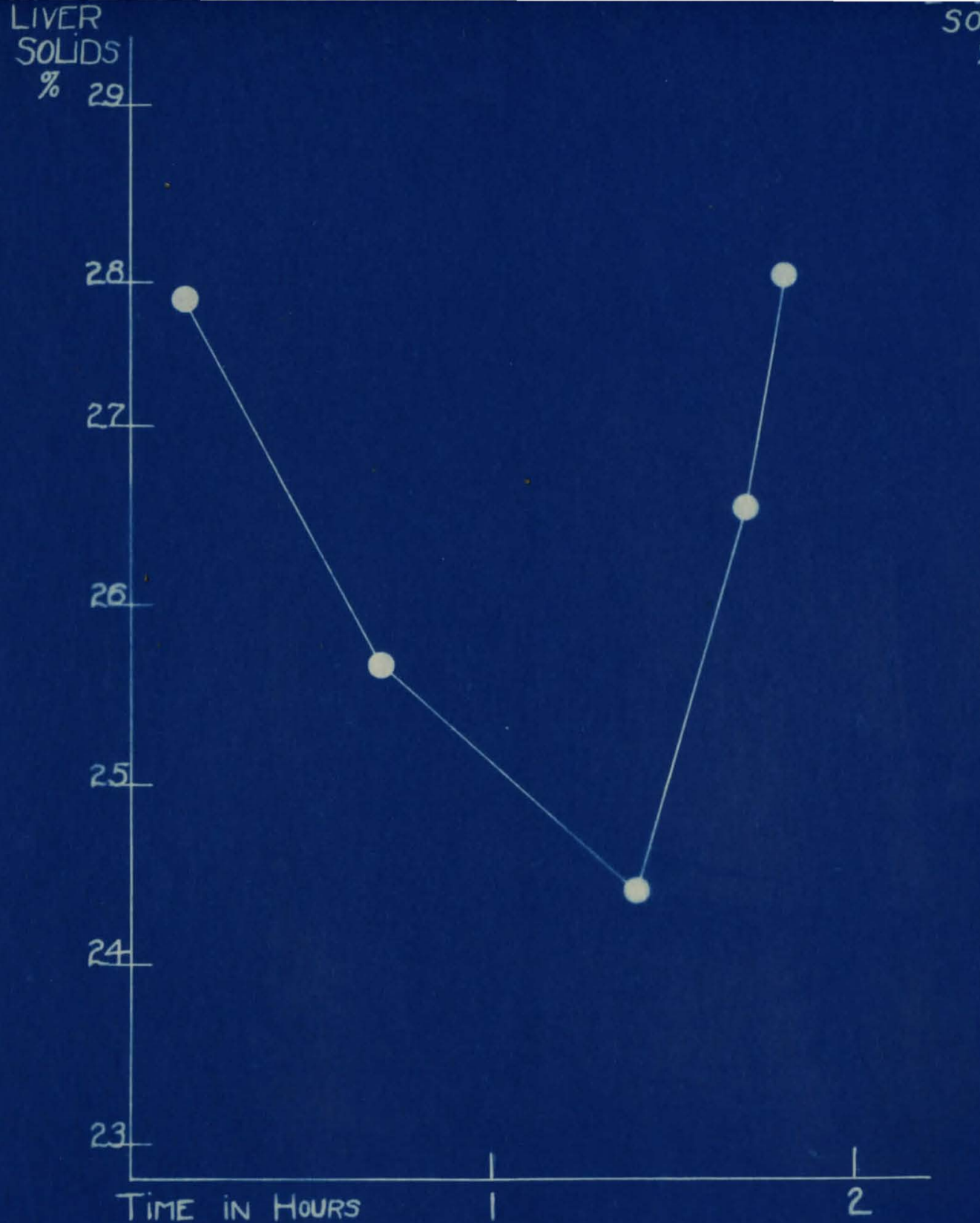

Fis. Xa

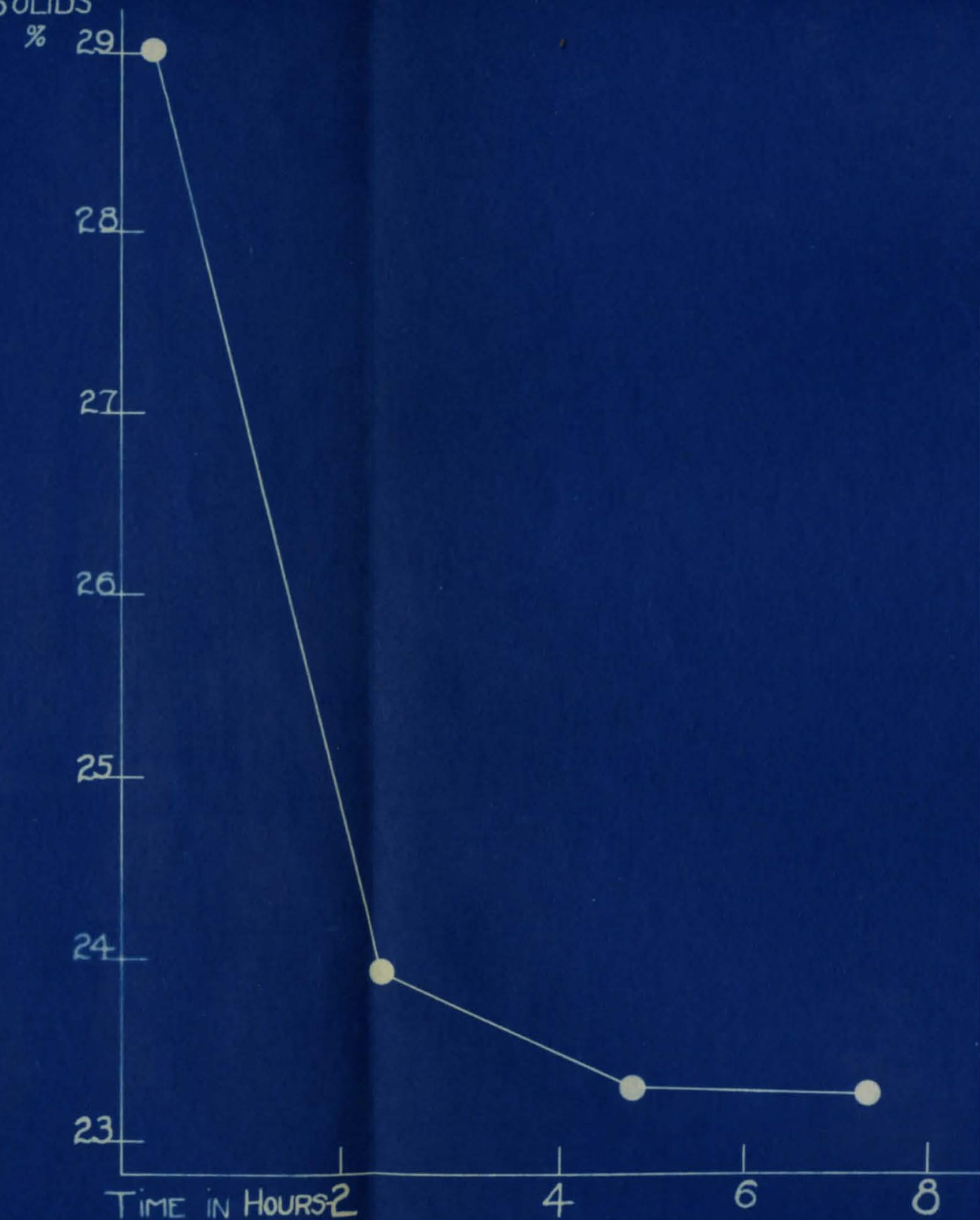

$F_{i}$. X b 
IIver had been induced to relinquish water. The blood specific gravity in the rabbit was reduced from 1.0531 to 1.0505 in thirty minutes; the temperature fell . $4^{\circ} \mathrm{F}$. in the interval, also the temperature was high et time of death and vasomotor responses were as usual with the ears very. vascular (see Table X), samples of liver were taken for histological studies as before.

Another litter experiment using eight New Zealand rabbits was done March l8th with same procedure and methods as before with the exception that two additional liver denervations were made.

The liver from simple puncture showed a reduction of solids; puncture with heating of basal ganglia showed increased solids while puncture with cooling showed a decrease of solids from simple puncture. The rabbits having the liver denervated showed still a low percent of liver solids which was not appreciably affected by heating or cooling with exception of the sample from the right lobe; the converse relationship would indicate that that lobe had been incompletely denervated. In as much as this same incongruity appeared in the experiment of February 24th, It is reasonable to suppose that some stray nerve fibers reached the right lobe from below the portal vein or from above the diaphragm (see Table XI). 
TABLE XII

This table was compiled from litter experiments on normal healthy. New Zeal and rabbits.

LIVER SOLIDS

$\begin{array}{cc}\text { Number } & \text { Average } \\ \text { of } & \text { Liver Solids } \\ \text { Rabbits } & \%\end{array}$

Normal

6

28.3

Puncture

5

26.6

Puncture

with Heat

2

27.4

Puncture

with Cold

2

26.4

Hepatic Artery

cut

5

22.9

Normal killed

under Ether

2

26.5

Normal recovery

from Ether

2

28.1 
Table XII derived from the combined experiments in this series of litter experiments gives a comparative relation of liver solids to operative procedure.

\section{Discussion.}

The liver solids from the litter experiments show a close reciprocal relationship to the concentration changes of the blood derived from puncture fever and from heating and cooling of the basal ganglia. That the water content of the liver is variable in different lobes in the operated rabbits offers no particular difficulty except to diminish the contrast in results which is apparent in spite of that inconsistancy. Furthermore, the reduction of liver solids in simple puncture fever is almost the same as the reduction found in Marshall's (18) rabbits last year from cocaine fevers and degree of reduction of solids from the onset of fever.

Control of the blood concentrating function of the liver must therefore, be included in the heat regulating mechanism which has its nervous center in the basal ganglia. While effective vasomotor responses persist in all the procedures, the liver has been shown to be the principal agent in regulating the fluid content of the blood. 
THE HISTOLOGY OF THE LIVER AS AFFECTED BY THE VARIOUS PFOCEDURES USED IN THESE EXPERIMENTS . 
The Histology of the Liver as Affected by the Various Procedures Used in These Experiments.

The brains of the rabbits used were examined to confirm the entrance of the hollow tube into the region of the basal ganglia. No punctures were found which did not penetrate the structure of the brain adjacent to the basal ganglia.

The samples of liver which were taken from animals in each type of procedure were preserved in formalin, embedded in paraffin and stained with eosin haematoxylin. These show the following characteristics as revealed in examinations of fields from which the accompanying photomicrographs were taken.

Plates Ia and Ib - The liver from rabits having had cerebral puncture only.

The microscopic examination of sections of liver from rabbits which have had simple puncture and were in a febrile condition at the time of death, shows a syncytium like organization of the liver cells with the central veins very markedly constricted, to the extent that the sinusoids are obliterated by the swelling induced by the imbibed fluid.

The Kupfer cells are compressed to slit like form and the liver cells appear hydropic, angular in outline and greatly enlarged. In a large percent of the cells in which the cytoplasm 
appears bydropic, the cytoplasmic particles are aggregated into coarse granules which are not uniformly distributed. However the nuclei are still relatively normal in size and shape; that is, rounded in outline and retain their homogentous dark staining properties.

The cells in areas farthest from the central veins show the greatest vaculated or hydropic condition. These cells are also more deficient in granular cytoplasmic stuff.

Plates IIa and IIb - The microscopic examination of sections of liver taken from rabbits which have had heat applied to the basal ganglia, shows the liver cells to be of compact cytoplasmic organization with cord like arrangement of normal liver. The sinusoids are very pronounced and the liver cells are relatively small. The cell outlines are very definitely not angular. The granules of the cytoplasm are small and compact, being uniformly distributed throughout the cell. The nuclei are darker staining and are more homogeneous in their make up than the nuclei of cells in Plates I and III. The cells have unquestionably lost fluid which fact effects the compact and rounded appearance.

Plates IIIa and IIIb - In the microscopic examination of sections of liver taken from rabbits after cold had been applied to the basal ganglis, the tissue seems to have lost its cord-like organization and has assumed a syncytium-like character. The 
sinusoids are almost entirely obliterated with the exception of a very small area adjacent to some of the central veins. The Kupfer cells are elongated and flattened as if they were under considerable pressure resulting from the greatly increased size of the liver parenchyma. The individual cells in addition to their great enlargement show that the cytoplasmic particles are aggregated in relatively bare granules, and in this condition the cytoplasm presents a clear vaculated appearance with the large granules rather evenly distributed around the nuclei. The nuclei appear comparatively normal; that is, they are well defined, of normal shape and size although relative to the increased size of the cells they are smaller.

The central veins seem compressed showing a tendency for the intima to invaginate the lumen. No evidence of congestion is seen any place in the section.

In some areas the parenchymas is of paler staining reaction than in others and high magnification of these areas shows that the cells are enormously enlarged with relatively less granular aggregations and the nuclei are pale and lysed. 


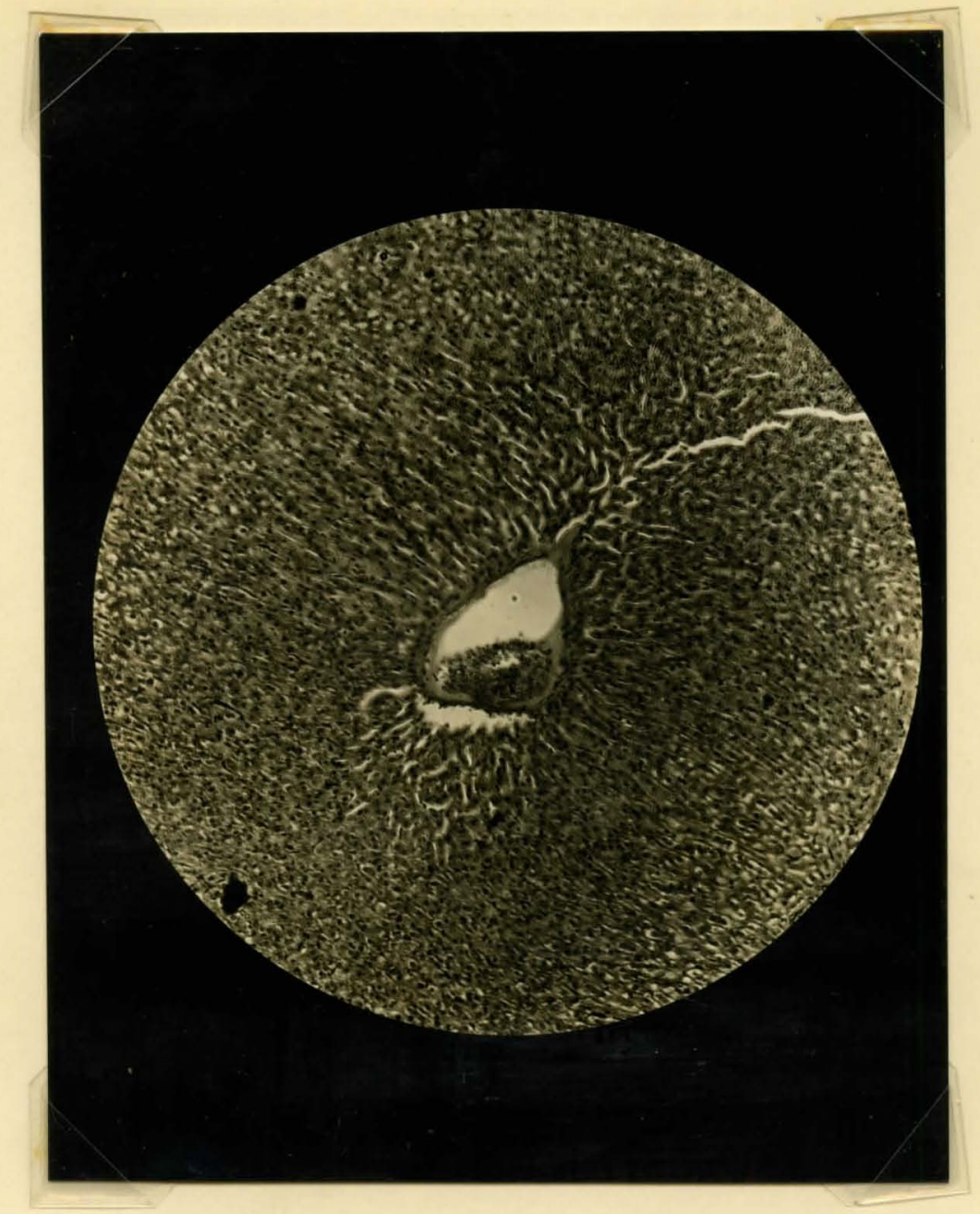

Plate Ia - 71 diameters magnification.

Photomicrograph taken of a section of liver from a rabbit having had simple puncture. The tissue was preserved in formalin, embedded in paraffin and stained in eosin haematoxylin. 


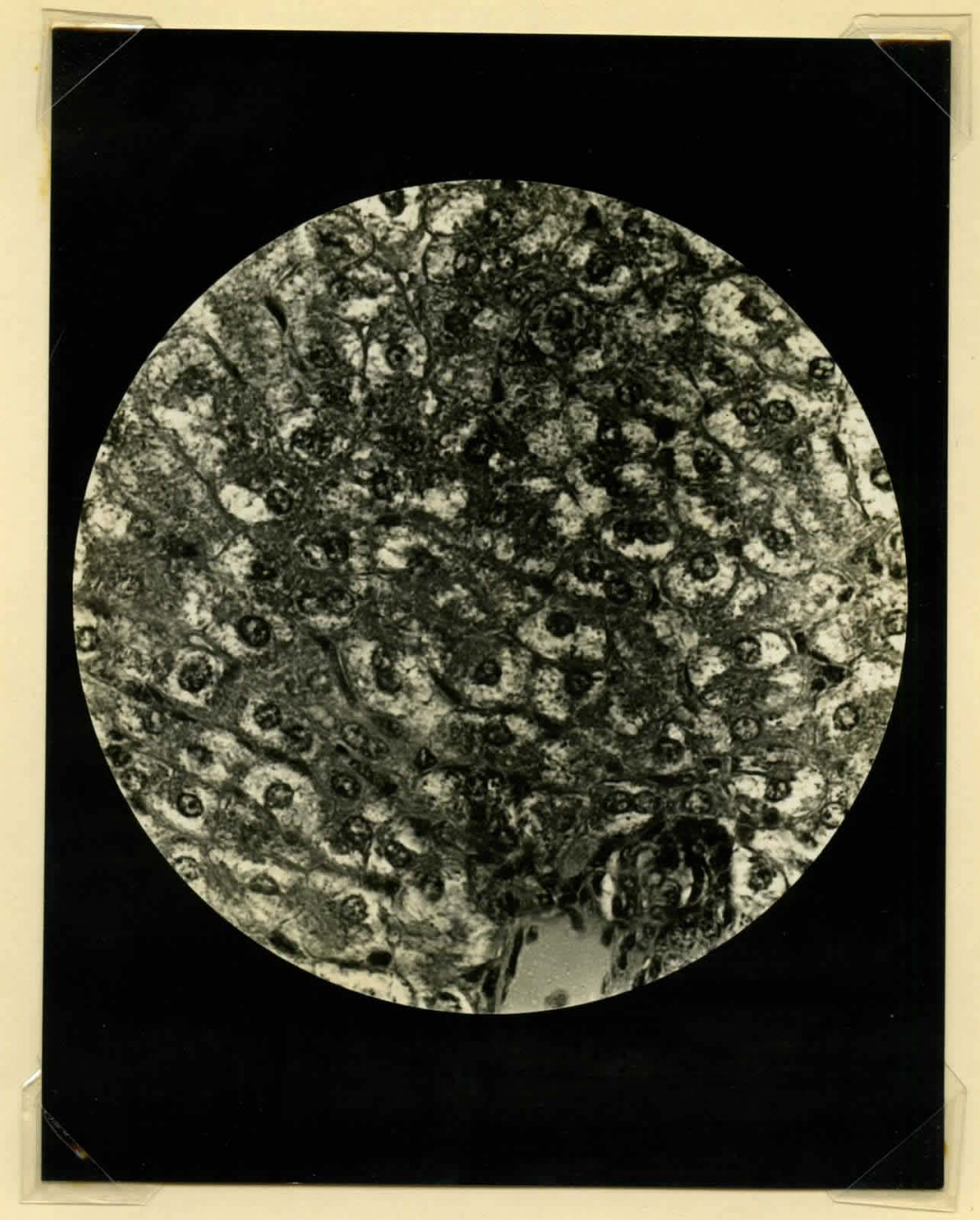

\section{Plate Ib - 390 diameters magnification.}

Photomicrograph taken of a section of liver from a rabbit having had simple puncture.

View is taken from the same field as Ia showing an area adjacent to a central vein. 


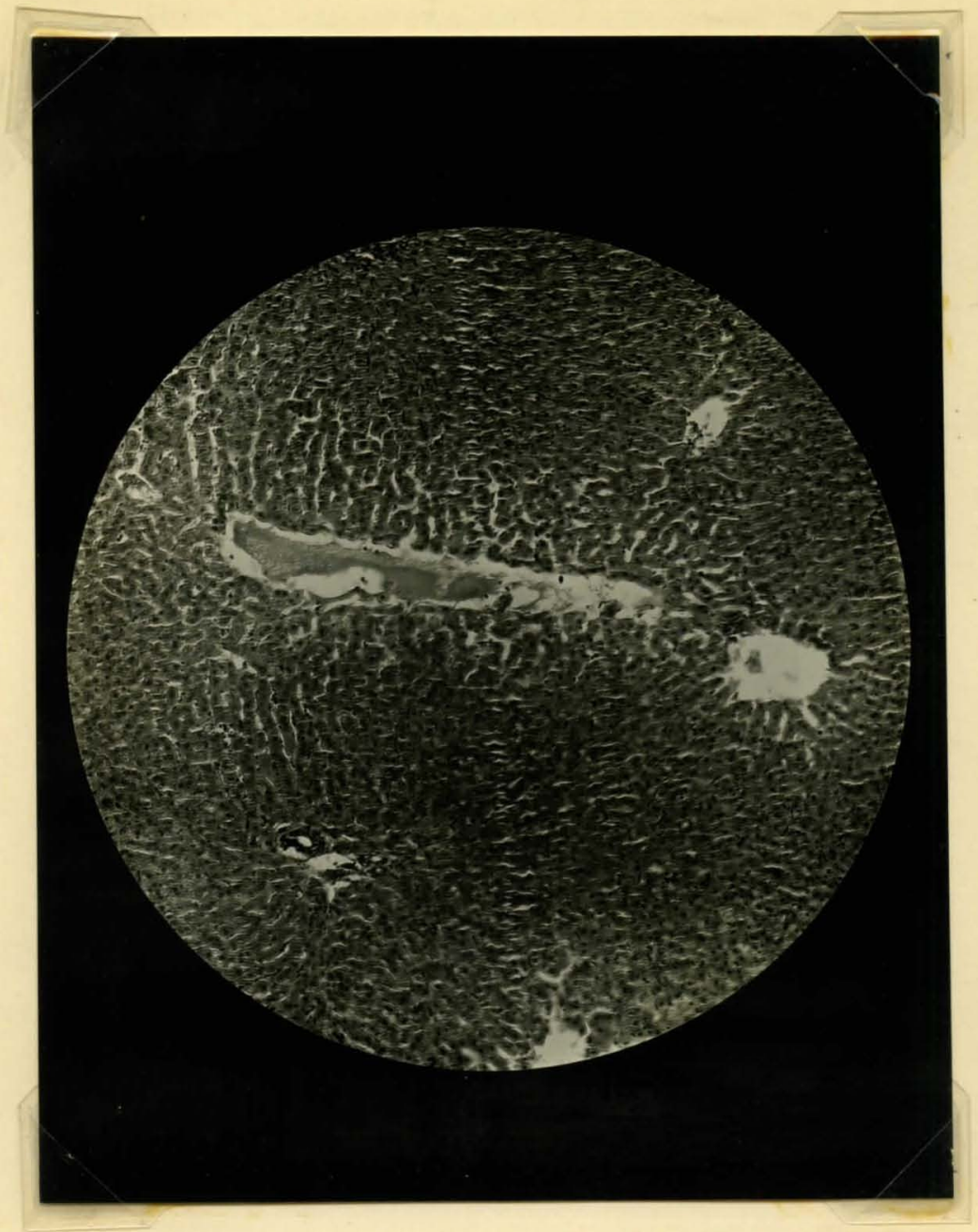

Plate IIa - $7 I$ diameters magnification.

Photomicrograph taken of a section of liver from a rabbit having had simple puncture with heat applied to basal ganglia. Tissue preserved in formalin, embedded in paraffin and stained in eosin haematoxylin. 


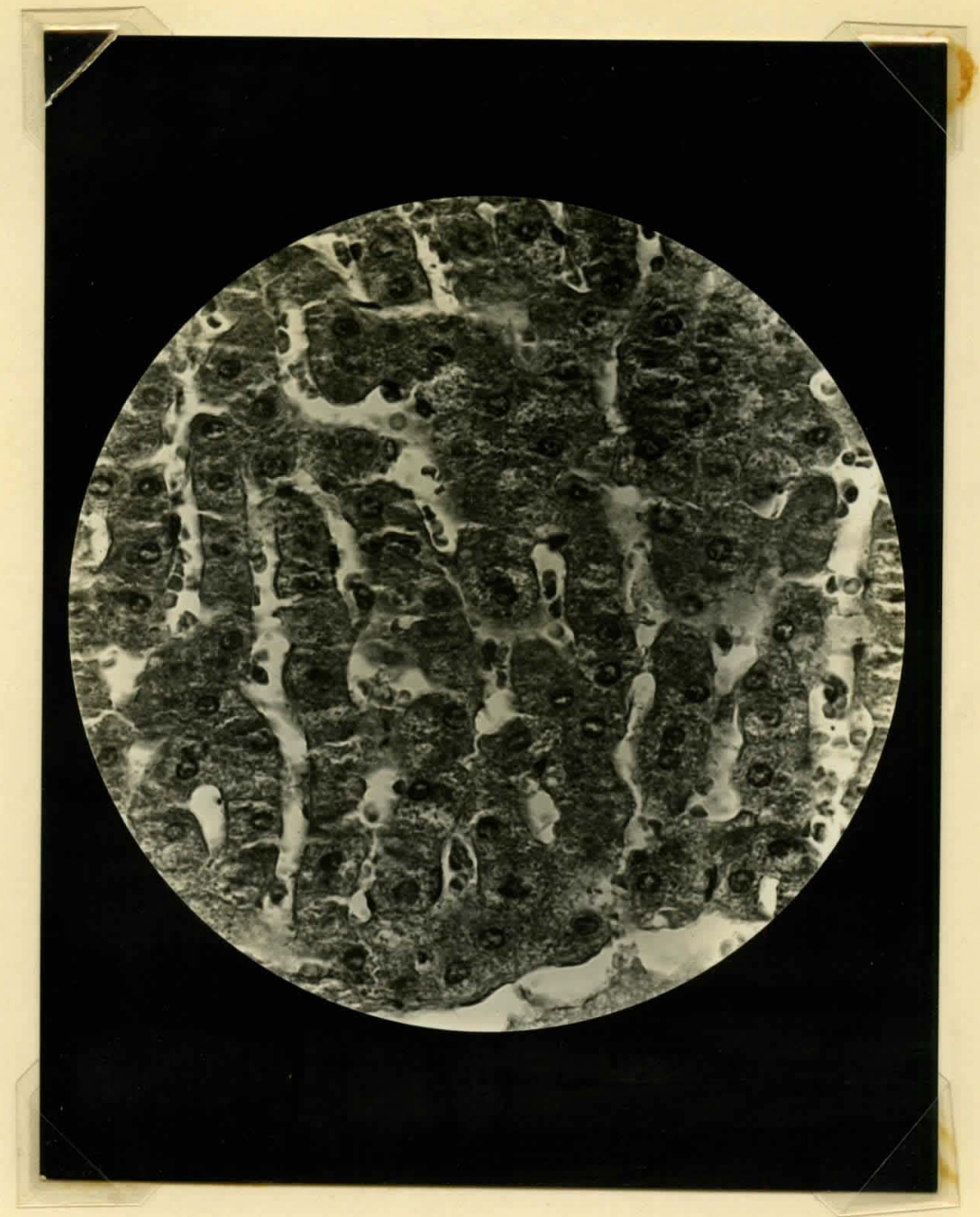

\section{Plate IIb - 390 diameters magnification.}

A photograph taken of a section of liver from a rabbit having had simple puncture with heat applied to the basal ganglia. View taken from field shown in IIa and shows area adjacent to a central vein. 


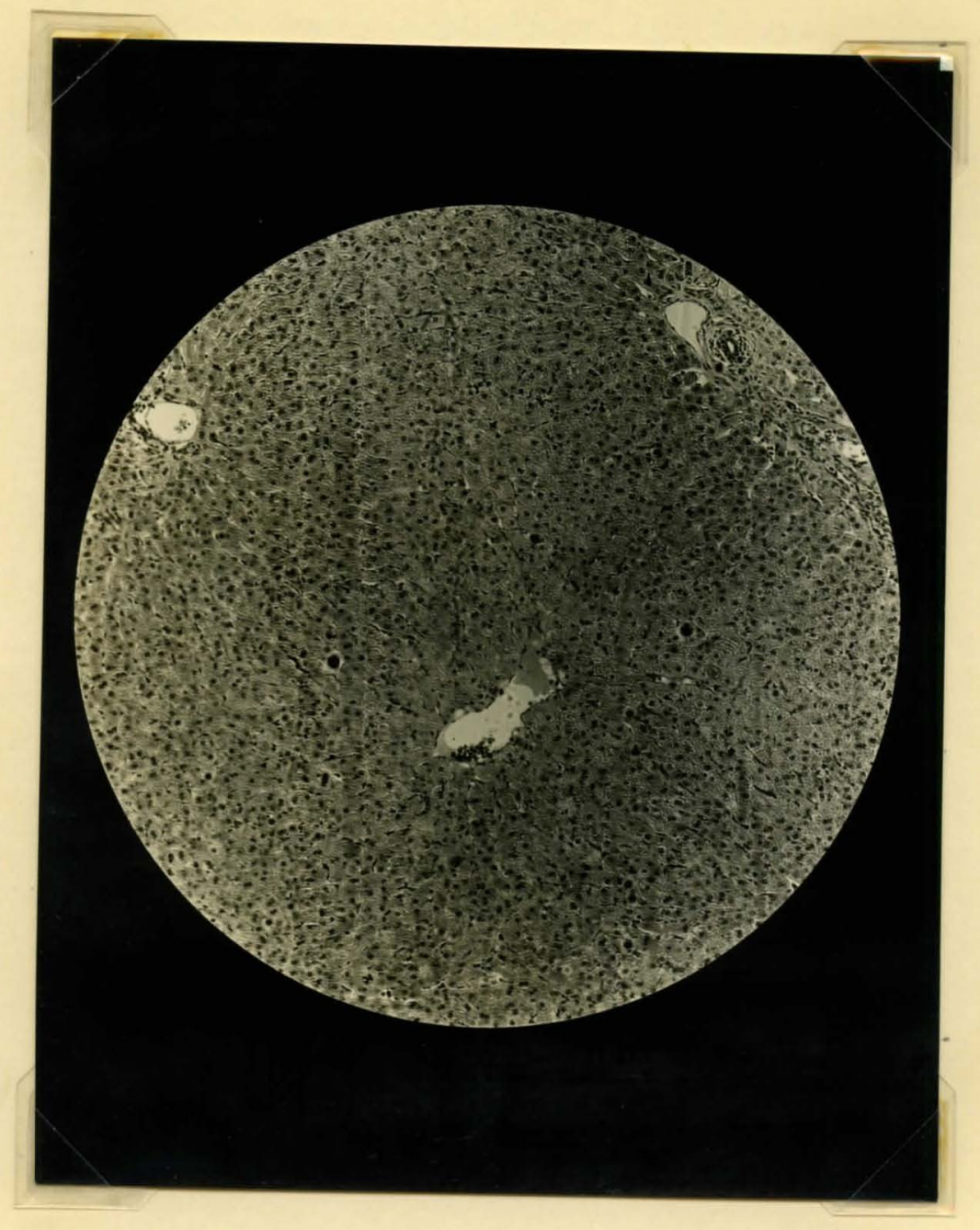

\section{Plate IIIa - 71 diameters magnification.}

A photomicrograph taken of a section of liver from a rabbit having had simple puncture with cold applied to the basal ganglia.

The tissue was preserved in formalin, embedded in paraffin and stained in eosin haematoxylin. 


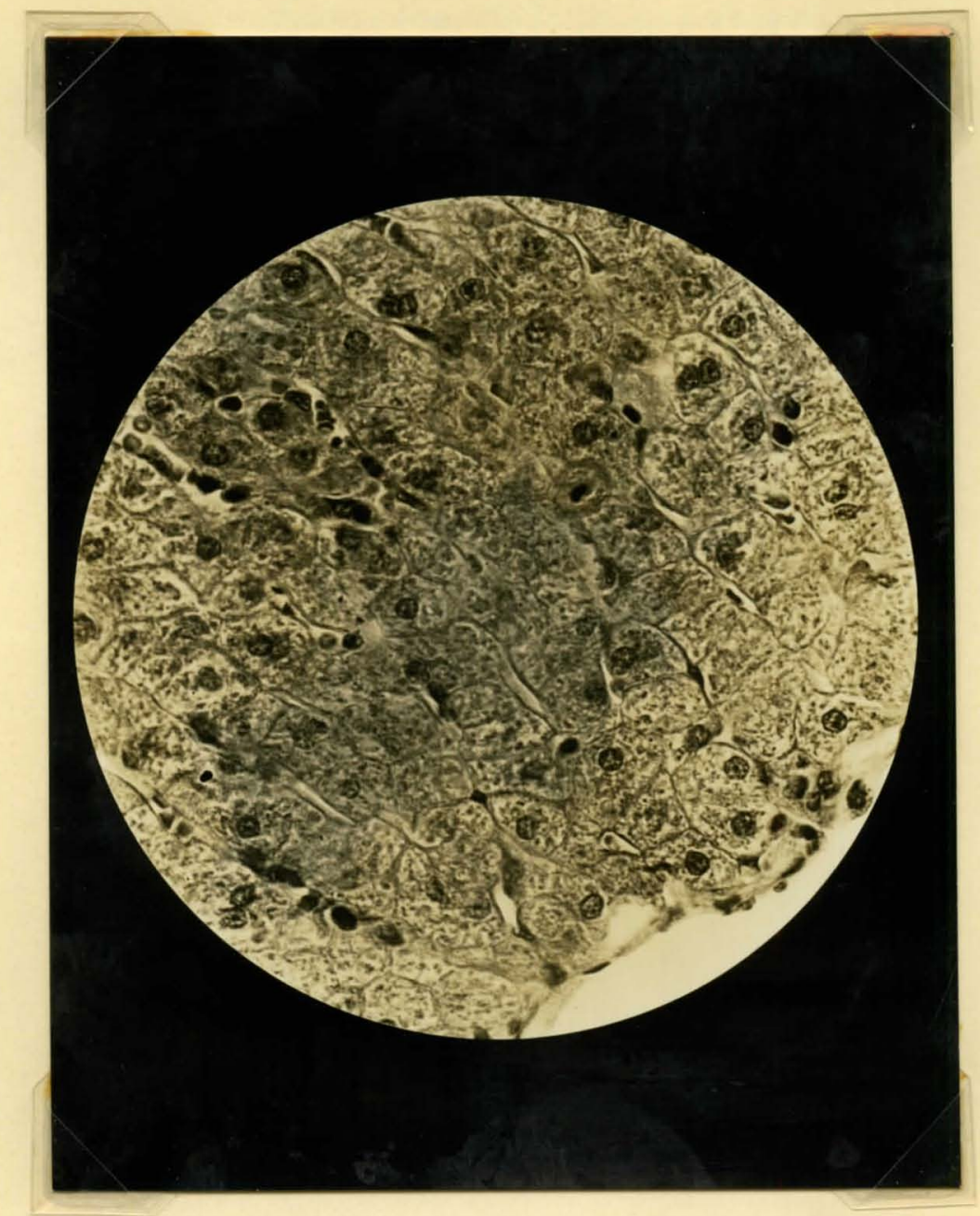

\section{Plate IIIb - 390 diameters magnification.}

A photomicrograph taken of a section of liver from a rabbit having had simple puncture with cold applied to the basal ganglia. The view is taken from the field shown in IIb, the area adjacent to a central vein. 
CONSIDERATION 


\section{CONSIDERATION .}

The microscopic examination of the liver reveals that in puncture fever and in instances when cold is applied to the basal ganglia, that the liver cells have taken up fluid; and in case of heating the basal ganglia, that the liver cells have given up fluid, have become smaller and are of more compact structure.

These findings substantiate the blood specific gravity and liver solids findings reported in this paper. 
SUMMARY 


\section{SUMMARY.}

1. Heat applied to the basal ganglia of rabbits caused a dilution of the blood associated with the known lowering of body temperature; the converse was found true of the application of cold.

2. Fever induced by puncture into the brain at the basal ganglia was found to be accompanied by a concentration of the blood.

3. Liver denervation increased the blood concentration which thereafter could be altered neither by heat puncture nor by heating or cooling of the basal ganglia.

4. Fluid lost from the blood during neurogenic fevers was shifted to the liver as shown by reduction of liver solids, conversely the liver surrendered fluid to the blood on remission of fever. This has been shown both chemically and histologically.

5. The rate of temperature rise in neurogenic fevers was found to be impaired by denervation of the liver. 
CONCLUS IONS 


\section{CONCLUSIONS .}

1. Fluid is lost from the blood in neurogenic fevers; being shifted principally to the liver.

2. This loss of fluid from the blood is controlled through a nervous mechanism which involves the liver.

3. Any stimulus effective for body temperature regulation when applied in the central nervous system also appears effective in controlling the blood concentrating function of the liver. 
ACKNOWLEDGEMENT.

It is now a pleasure to express my gratitude to Dr. H. G. Barbour for his invaluable direction and encouragement throughout this work; my thanks to Dr. A. J. Miller and his assistants from the Department of Pathology at the Louisville City Hospital for the kindness shown to me in preparing material for microscopical examination; and appreciation to Dr. S. I. Kornhauser of the Department of Anatomy for the preparation of the plates for the photo micrographs which have added materially to the completeness of this paper.

Benjamin F. Aydelotte. 
(1) Afanassiew, H. : uber anatomish veranderungon der Leber whrend vershiedener Thatigkeitenstandi - archiv fur Physiologie. Vol. 30, 1883.

(2) Barbour, H.G. and Hamilton, W.F. : The Falling Drop Method for the Determining Specific Gravity: Journ. Bio Chem: LXIX, 625-640, 1926.

(3) Barbour, F.G. and Hamilton, W.F. : The Falling Drop Method for Determining Specific Gravity. Some Clinical Applications. J. A. M. A. LXXXVIII; 91-94, 1927.

(4) Barbour, H.G. and Mroise, M.D.: The Mechanism of Cocaine Fever. Journ. Pharm. Exp. Therap. XXX, 270, 1922.

(5) Barbour, H.G. and Tolstoi, Edward: The Role of the Water Content of the Blood and its Control by the Central Nervous System. Am. Journ. Physiol. Vol. 67, No. 2, 1924.

(6) Beckman, Karl : Leber und Minerahaushalt. Zeitschrift fur die Gesamte Experimentelle ledizin, Vol. 59, 1929.

(7) Beckman, Karl : Leber und inineralhaushalt. Deutsches Archiv fur Klinische Hedizin. Vol. 160, 63-84, 1928.

(8) Beckman, Karl : Leber und Mineralhaushalt. Deutsches Archiv fur Klinische lledizin. Vol. 163, 164; 1929. 
(9) Beckman, Karl : Leber und Hineralhaushalt. Zeitschrift fur die Gesamte Experimentelle Medizin. Vol. 66, 1929.

(10) Beatty, J.M. and Dickson, W.E.C.: Thrombosis of Branches of Hepatic Artery: General and Special Pathology. Third Edition 795, 796.

(11) Lamson, Paul D. : The Role of the Liver in Acute Polycythemia: a Mechanism for the Control of the Red Corpuscle Content of the Blood. Journ. Pharm. Exp. Therap. Vol. VII, 18I; 1915.

(12) Lamson, Paul D. : Further Observations on Effect of shutting off Arterial Blood Supply to the Liver: the Reactions of the Normal Animal and Removal of Liver from Circulation. Journ. Pharm. Exp. Therap. Vol. IX, Nov. $3,1916$.

(13) Meutner,H. and Pick, E.P.: Huchener Med. Wochenschr NR 34, 1915.

(14) Plant, Rahal : Concerning Metabolism with Heat Regulation. Deutsches Archiv fur Medizin Vol. 160.

(15) Shlfer, Edward S.:F.R.S. Histology of the Liver: Essentials of Fistology, lith Edition. 360-369, 1920. 
(16) Lamson, Paul D. and Roca, John : The Liver as a Blood Concentrating Organ. Journ. Pharm. Exp. Therap. 481-497, 1926.

(17) Rogers, F.T. : Diuresis and Anhydremia Following Destruction of Thalamus. Am. Journ. of Physiol. IXVIII, 1924.

(18)Marshall, H.T. : The Fate of Water Lost from the Blood in Cocaine Fever and the Relation of This Water to the Febrile Process. Thesis presented to University of Louisville, 1930.

(19) Krumbhear, E.B. : Functions of the Spleen. Physiological reviews, Vol. 6, 1926, 168-191.

(20) Barbour, H.G. : Die Wirkung unnrittelbarer Erwärmung und abkulhling der Warmezentra auf die Kospertemperatur. Archiv 1. Exp. Path. u. Pharm. B. 70; 1-26. 